\title{
Bioremediation in Water Environment: Controlled Electro-Stimulation of Organic Matter Self-Purification in Aquatic Environments
}

\author{
Lucas Jobin ${ }^{1,2}$, Philippe Namour ${ }^{2}$ \\ ${ }^{1}$ University of Lyon, Université Claude Bernard Lyon 1, Institute of Analytical Sciences (ISA), Villeurbanne, France \\ ${ }^{2}$ IRTSEA, UR MALY (Freshwater Systems, Ecology \& Pollution), Villeurbanne, France \\ Email: philippe.namour@irstea.fr
}

How to cite this paper: Jobin, L. and $\mathrm{Na}$ mour, P. (2017) Bioremediation in Water Environment: Controlled Electro-Stimulation of Organic Matter Self-Purification in Aquatic Environments. Advances in Microbiology, 7, 813-852.

https://doi.org/10.4236/aim.2017.712064

Received: September 28, 2017

Accepted: December 22, 2017

Published: December 25, 2017

Copyright (๑) 2017 by authors and Scientific Research Publishing Inc. This work is licensed under the Creative Commons Attribution International License (CC BY 4.0). http://creativecommons.org/licenses/by/4.0/

\begin{abstract}
This review describes a new means of control and stimulation of microorganisms involved in the bioremediation of sediments and waterlogged soils. This emerging technology is derived from sedimentary microbial fuel cells, and consists in ensuring aerobic respiration of aerobic microbial populations in anaerobic conditions by means of a fixed potential anode in order to evacuate the electrons coming from the microbial respiratory chains. This review describes the conceptual basis of the electro-bioremediation, the material devices used (electrode set-ups and spacing), and finally studies the various devices published since the bench tests until the scarce in-field implementations.
\end{abstract}

\section{Keywords}

Organic Matter, Bioremediation, Electro-Microbiology, Self-Purification Enhancement, Greenhouse Gas, Water Body

\section{Introduction}

The world's population grows and concentrates in urban areas [1]. This demographic change leads to landscape transformations that have many effects on water systems. The most consistent and pervasive one is an increase wastewater discharges in water bodies [2]. Wastewater discharges cause serious health and environmental concerns: 1) Emission of toxic (hydrogen sulphide, $\mathrm{H}_{2} \mathrm{~S}$ ) or noxious (methane, $\mathrm{CH}_{4}$ ) gases from sewer systems [3] [4] [5]; 2) Urban wet-weather runoff from impervious surfaces is routinely discharged from Combined Sewer 
Overflows (CSOs) into waterways without further treatment, having a significant impact on the quality of receiving waters; and CSOs are now recognized as a major source of pollutants in receiving water [6] [7]. Untreated urban wastewater discharged into the rivers concentrates in sediment and causes rapid anoxia due to the huge quantities of biodegradable organic matter (OM) discharged in river far exceeding its self-purification capacity.

In latest decade, the electro-bioremediation has attracted growing attention, but to date no review has focused on means to direct it, to limit its GHG emissions [8]-[14]. This review focuses on the controlled extraction of electrons, to enhance the biodegradation of organic matter in aquatic environments, while reducing the GHG emissions. It does not deal with electron injection to reduce persistent organic pollutants (POPs) or methods based on low-voltage seawater electrolysis to generate oxygen or chlorine [15]. Electro-bioremediation is an emerging technology, also, the number of publications about it on is very low, and can be counted on the fingers. Also, the bases of electrochemical stimulation of self-purification are identical to the MFC ones (potential regulation to be selective in the first, and maximum electron extraction, without any potentiometric regulation in the second). However the advances in MFC devices are of great help to optimize a stimulation device of self-purification: the processes are the same, only electron management differs.

\section{Self-Purification in Water Bodies}

According to European Environmental Agency, self-purification is the ability for any water body to removal the organic material, mineral nutrients, or other pollutants by the natural activity of its resident biological communities. It is a natural biogeochemical processes leading to the oxidation and mineralization of organic matter, and it is particularly active in the river underflow (hyporheic zone) where a redox gradient naturally installs [16] [17].

\subsection{Natural Sediment Redox Processes}

Sediment is generally oxygen poor (consumed by microorganisms) and OM laden, so microbial metabolism maintains reducing conditions in sediment where the biodegradation reactions take place according to a redox gradient (Figure 1) [18] as the biodegradation effectiveness is often limited by the low availability (presence and mobility) in electron acceptors (e.g. $\mathrm{O}_{2}, \mathrm{NO}_{3}^{-}, \mathrm{Fe}$ (III), $\left.\mathrm{Mn}(\mathrm{IV}), \mathrm{SO}_{4}^{2-}\right)$, in these conditions the microbial metabolism maintains reducing environment in the porous sediment and the biodegradation reactions are gradually changing, according to a redox gradient [19]. In addition, environmental conditions strongly modulate the biological processes: 1) temperature is a variable that strongly drives the biological activities; 2) $\mathrm{OM}$ and $\mathrm{NO}_{3}$ (exogenous inputs or $\mathrm{NH}_{4}$ nitrification) availabilities are main reactants for denitrification [20]. The redox potential is a key element closely related to the $\mathrm{pH}$ and the electron acceptor availability (Figure 1). 


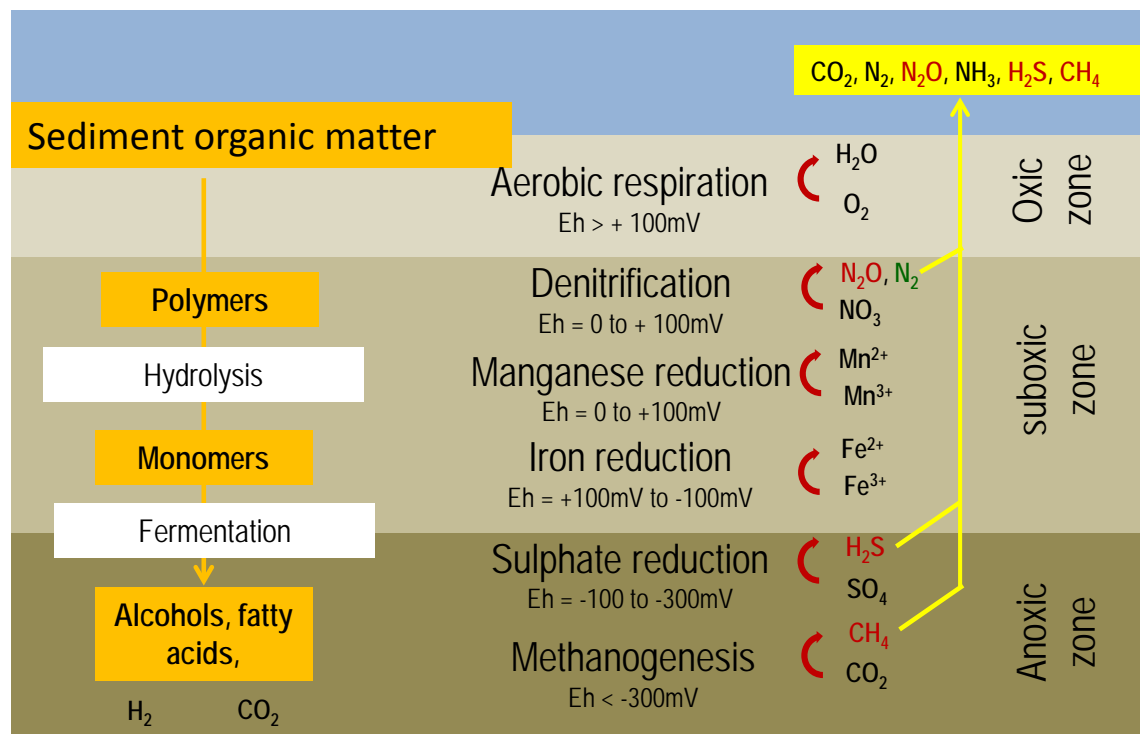

Figure 1. Schematic localization of different microbial processes in the sediment according the redox potential. The order of electron acceptors displayed in an idealised system is $\mathrm{O}_{2}, \mathrm{NO}_{3}^{-}, \mathrm{Fe}(\mathrm{III}), \mathrm{Mn}(\mathrm{IV}), \mathrm{SO}_{4}^{2-}, \mathrm{CO}_{2}$ (adapted from [18] p. 573; [21] [22]).

In running waters, bio-geo-electrochemical processes are not so gradually organized as described in lake sediments according to depth [18] forming a stratified redox gradient, from oxic condition, to suboxic and anoxic conditions (Figure 1). Preliminary results showed a high sediment functioning heterogeneity according water flow, geomorphology, hyporheic and nutrient fluxes due to hydraulic conductivity and hydraulic gradient [23]. The redox cycling of organic $\mathrm{C} \& \mathrm{~N}$ not only drive the micro- and macro-biological communities, but also have implications for global nutrient balances and climate change. So, $\mathrm{CH}_{4}$ emissions from wetlands, rice paddies, and thawing permafrost soils significantly contribute to the overall GHG budget on Earth [19].

\subsection{Gas by-Products of Self-Purification}

Water system metabolic activity transforms a huge fraction of OM [24], and N \& C content are recycled and eliminated at rates up to 70\% [25] [26] in gaseous forms [27] [28] [29] (Figure 2). During anaerobic OM degradation, water systems release major GHGs, namely carbon dioxide $\left(\mathrm{CO}_{2}\right), \mathrm{CH}_{4}$ and nitrous oxide $\left(\mathrm{N}_{2} \mathrm{O}\right)$ [30] [31] [32] [33]. Few studies directly measure GHG emissions with floating chambers and the dissolved forms [34] [35] [36] [37]. $\mathrm{N}_{2} \mathrm{O}$ and $\mathrm{CH}_{4}$ are important GHG, with a Global Warming Potential of respectively 298 and 24 relative to $\mathrm{CO}_{2}$ over a 100 -year period [38]. If about $60 \%$ of global $\mathrm{CH}_{4}$ emissions are anthropogenic, the most important source of uncertainty on the total budget is attributable to emissions from wetland and other inland waters [39]. Also, the importance of inland waters in the overall GHG budget was recently reassessed as the total $\mathrm{CH}_{4}$ emission from freshwaters is esteemed to be $103 \mathrm{Tg}$ of $\mathrm{CH}_{4} /$ year. Expressed as $\mathrm{CO}_{2}$ equivalents (eq), this corresponds to $0.65 \mathrm{Pg}$ of $\mathrm{C}\left(\mathrm{CO}_{2}\right.$ eq)/year or $25 \%$ of the estimated land GHG sink, assuming that $1 \mathrm{~kg}$ of $\mathrm{CH}_{4}$ 


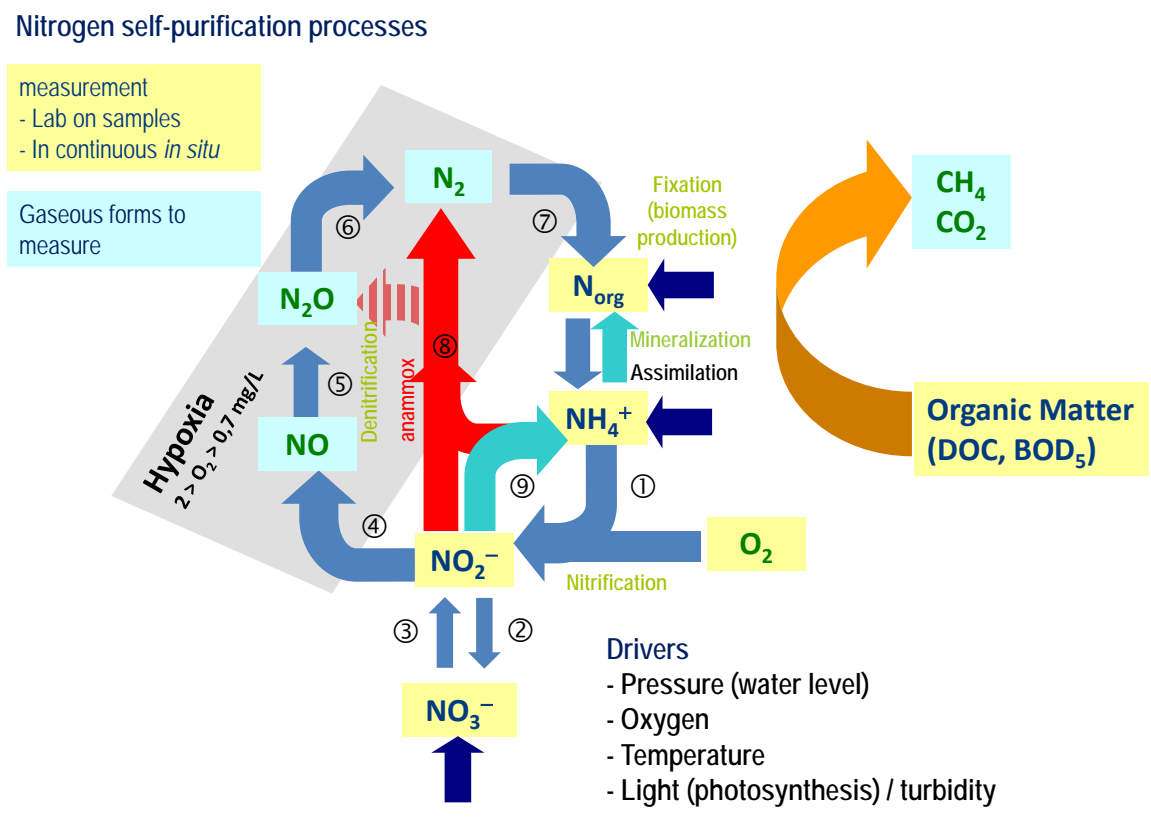

Figure 2. Diagram of the various stages of biological nitrogen transformation and their coupling with the carbon cycle during the river self-purification (from [52] [53]).

corresponds to $25 \mathrm{~kg}$ of $\mathrm{CO}_{2}$ over a 100 year period [40]. Total waterborne GHG emissions vary considerably according to site type, with fairly low emissions from forestry-drained boreal bog (circa $10^{3} \mathrm{~kg} \mathrm{CO}$ eq/(ha.yr)), but substantially higher emissions ( $\left.3-4.5 \times 10^{3} \mathrm{~kg} \mathrm{CO} \mathrm{Cq}_{2} \mathrm{e} / \mathrm{ha} \cdot \mathrm{yr}\right)$ ) for the boreal peat extractions, temperate grasslands and cleared tropical forests [41]. While the $\mathrm{CH}_{4}$ fluxes ranged between 7.3 and $67.7 \mathrm{mg} /\left(\mathrm{m}^{2} \cdot \mathrm{h}\right)$ from vegetated surface in natural wetlands, they varied between 1.53 and $3.07 \mathrm{mg} /\left(\mathrm{m}^{2} \cdot \mathrm{h}\right)$ in constructed ones [42]. Some wetlands as the paddy fields are supposed contribute up to $20 \%$ of the global total anthropogenic $\mathrm{CH}_{4}$ emissions [43]. Overall, waterborne carbon emissions may contribute about $1-4 \times 10^{3} \mathrm{~kg} \mathrm{CO}$ eq/(ha.yr) of additional GHG emissions from drained peatlands. In river the two specific problems of self-purification are the length of stream needed to reach this removal efficiency and the GHG emission. The magnitude of the emissions varies from one study to another, from barely ten [44] to serval hundreds of $\mu \mathrm{g} /\left(\mathrm{m}^{2} \cdot \mathrm{h}\right)$ [45] for $\mathrm{N}_{2} \mathrm{O}$ and from 1 to $500 \mu \mathrm{mol} /\left(\mathrm{m}^{2} \cdot \mathrm{h}\right)$ for $\mathrm{CH}_{4}$ [46]. But several studies show that $\mathrm{GHG}$ emissions are closely dependent on the organic input for $\mathrm{CH}_{4}$ [47] [48] and $\mathrm{N}_{2} \mathrm{O}$ [20]. OM inputs (e.g. CSOs) must therefore strongly affect river emissions Different mechanisms are at the origin of GHG $\left(\mathrm{N}_{2} \mathrm{O}, \mathrm{CH}_{4}\right)$ [18] [49]. The main aquatic sources of $\mathrm{N}_{2} \mathrm{O}$ are nitrification and denitrification [50]. Although not always observed, anaerobic ammonium oxidation (anammox) may also contribute to $\mathrm{N}_{2} \mathrm{O}$ formation [51].

The ultimate step of OM degradation in anoxic condition is methanogenesis. $\mathrm{CH}_{4}$ is predominantly produced from either acetate (acetoclastic methanogenesis) or hydrogen and carbon dioxide (hydrogenoclastic methanogenesis) [54] by methanogens having the ubiquitous methyl-coenzyme $\mathrm{M}$ reductase (mcrA) in all 
known Archaea methanogens [55]. The ${ }^{12} \mathrm{C} /{ }^{13} \mathrm{C}$ isotopic ratio allows differentiating these two possible pathways at the origin of emitted $\mathrm{CH}_{4}$ [56] [57]. Whether for $\mathrm{N}_{2} \mathrm{O}$ or $\mathrm{CH}_{4}$, emission level is highly dependent on the activity of microorganisms involved [58] [59] therefore control of gaseous emulsions requires control of microbial activities.

\section{Bio-Electrochemical Remediation: Some Definitions}

According to the United States EPA, Bioremediation is "an engineered technology that modifies environmental conditions to encourage microorganisms to destroy or detoxify organic and inorganic contaminants in the environment'. Technologies can be generally classified as in-situ bioremediation treating the contaminated medium on the site or ex-situ bioremediation involving the contaminated medium extraction to treat it elsewhere [60]. Many techniques to remediate a polluted water body are applied separately or in synergy way: 1) physical-chemical technologies, and 2) biological technologies or bioremediation, exploiting the self-purification capacity to assimilate organic matter [12] [61]. Current eco-engineering practices attempting to improve bioremediation focus on physical actions through geomorphological modifications as constructed swales or riffles across urban creeks [62] [63] or constructed wetlands [64]. But this way is not always possible in urban areas where space is often scarce and expensive. The present-day common approach in bioremediation technology, is to add sufficient chemical electron donors (e.g., lactate, acetate, citrate, or $\mathrm{H}_{2}$ ) to feed the intrinsic microbial catalysts either ex-situ, in cumbersome plants requiring tanks, pumps and pipes, or in-situ requiring chemical injections in the environment [65] [66]. Few devices use the cathode to directly inject electrons for the clean-up of halogenated solvents [67], nitrate [68], to recalcitrant wastes [69]. The recent developments in electro-microbiology may pave the way to new possibilities to enhance bioremediation processes and direct the degradation products, through an electrochemical management of microbial populations able to enhance the bioremediation of polluted water environments and control the GHG and toxic gas emissions.

\subsection{Electro-Microbiology}

Over the past decade, a new biological discipline, the electro-microbiology, was a rapidly emerging field from the microbiology. It deals with the interactions between microorganisms and electronic devices, and novel electrical properties of microorganisms [70]. Electro-microbiology technologies are founded on the fact that: growth and survival of any living organism requires continuous electron exchanges between electron donors and acceptors, these electron carriers are usually some chemical compounds acting as shuttles in electro-transfer mechanisms. For aerobic organisms, $\mathrm{O}_{2}$ is the terminal electron acceptor, but in case of anaerobic organisms other electron acceptors can be used, such as nitrate $\left(\mathrm{NO}_{3}^{-}\right)$, $\mathrm{Fe}(\mathrm{III}), \mathrm{Mn}(\mathrm{IV})$, sulphate $\left(\mathrm{SO}_{4}^{2-}\right)$, or organic acids as acetate or fumarate. 
According the redox potential of acceptor/donor involved, these redox compounds have a lower energy yield than $\mathrm{O}_{2}$, so anaerobic respiration is less energy efficient and anaerobes grow at slower rates than aerobes. Additionally, some facultative anaerobes can use either $\mathrm{O}_{2}$ or alternative terminal electron acceptors for respiration depending on the environmental conditions.

Bacteria can direct transfer their electrons to solid surfaces acting as anode by different electron-transferring mechanisms summarized in Figure 3 [14] [70] [71]:

1) Indirect electron transfer by externally added mediators (methyl-viologen aka Paraquat; potassium ferricyanide; methylene blue or natural mediators (humic substances, $\mathrm{Fe}(\mathrm{II}) / \mathrm{Fe}(\mathrm{III})$, or $\mathrm{SO}_{4}^{2-} / \mathrm{H}_{2} \mathrm{~S}$ [72] [73] [74]);

2) Indirect electron transfer by self-produced mediators (electron shuttles) released by microorganisms (e.g. flavins of Shewanella sp. or piocyanin of Pseudomonas $s p$.), the oxidized mediator is reduced on the outer cell membrane, and then the reduced mediator transfer it electron to anode. This transfer mechanism depends on diffusive fluxes inside the biofilm;

3) Short-range direct electron transfer by outer membrane-bound redox systems, such as c-type cytochromes, to anode (Clostridium sp.; Desulfotomaculum sp.; Shewanella sp.; Aeromonas sp.) [75] [76] [77];

4) Long-range direct electron transfer through the biofilm via electrically conductive "nanowires" (pili), Geobacter sp.; Desulfuromonas sp.) [78].

A smart solution is to supply electron acceptors via direct electrochemical means, forming a Microbial-Electrochemical System (or Bio-Electrochemical Systems aka BESs). It harnesses the microbial ability to direct or indirect transfer electrons to solid surfaces by using a conductive electrode acting acts as either an electron acceptor or donor depending on the polarity conditions.

(1)

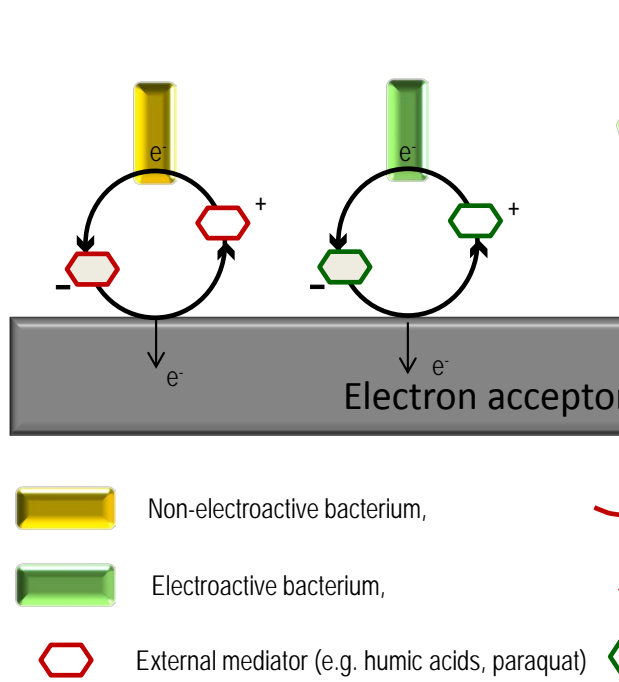

(3)

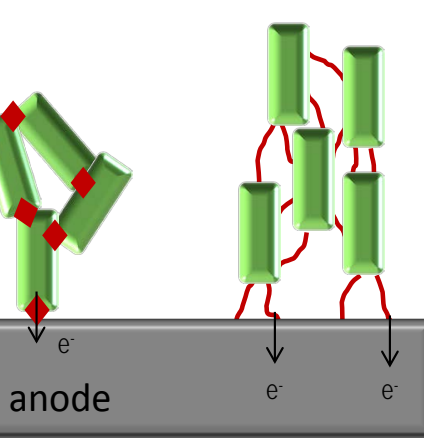

Outer membrane cytochrome

Self-produced mediator (e.g; flavins, pioyanin)

Figure 3. Models for electron-transfer mechanisms at the anode (adapted from ref. [70]). 


\subsection{Microbial Fuel Cells (MFC)}

Microbial Fuel Cell is a BES which generates electricity, and Microbial Electrolysis Cell (MEC) is a BES requiring a power supply to drive non-spontaneous reactions. Many of the recent advances in the electron transfer between microbes and electrodes have arisen from the study of MFCs, devices initially designed for harvesting electricity from OM degradation [14] [79] [80]. In an MFC, electricity is produced by extracting electrons in anoxic conditions by an external circuit and combining them at the cathode under oxic conditions with $\mathrm{H}^{+}$and $\mathrm{O}_{2}$ from the air, to form $\mathrm{H}_{2} \mathrm{O}$. In $\mathrm{MEC}_{2}$ is banned at the cathode, electrons can merge with $\mathrm{H}^{+}$to give $\mathrm{H}_{2}$. MECs can clearly yield other high value products, but these process needs to inject energy into the system.

\section{Sedimentary (SMFC) and Benthic Microbial Fuel Cell (BMFC)}

Initially designed to run with marine sediment rich in organic matter and sulfides [81], now SMFCs run with all sediments including waterlogged soils such as wetlands and rice paddies. According to Li et al. typology [10], a SMFC is a lab-scale set-up derived from MFCs, in which microbial consortium is a sediment, used to assess and optimize parameters under controlled conditions. Basic benthic microbial fuel cell (BMFC) is an outdoor set-up, consisting in an anode buried in the sediment anoxic zone and a cathode floating in the oxic superficial water; both connected through an external electric-circuit [82] [83], in such way to drain electrons from the anode acting as a powerful electron acceptor for microorganisms nearby anode, enhancing their respiration and thus the oxidation of sediment organic matter and contaminants associated. BMFC is a bit different from SMFC, the latter also utilizes sediment as the fuel source, but is not an in-situ set-up working in an actual water body and sediment, thickness replaces the proton permeable membrane. Several researchers have revealed the possibility of using BMFC as power source in marine [83] [84] [85] or freshwater [86] [87] [88] [89] environments.

BMFC can be used to explore some new bioremediation ways, which neither seek the maximum electron mining, nor inject energy to catalyse high added value products. The electron flux is managed to maintain an anode microbial population conducive to the $\mathrm{MO}$ biodegradation, and avoiding the production of undesirable gases $\left(\mathrm{N}_{2} \mathrm{O}, \mathrm{CH}_{4} \& \mathrm{H}_{2} \mathrm{~S}\right)$. The surplus collected electrons will go power the potentiostat, the sensing and control device, in charge to keep a proper voltage. The BMFC principle applied to constructed wetlands leads to the emergence of new environmental engineering, see below $\$ 5.2$.

\subsection{Electrochemical Bioremediation}

Bioremediation aims at increasing the $\mathrm{OM}$ assimilation while overcoming the microbial metabolism limits due to a shortage of electron acceptors. A basic approach is to provide chemical compounds as electron acceptors (i.e., oxidation) to increase OM degradation or electron donors (i.e. reduction) to increase the 
refractory OM degradation (e.g. organo-halogenated pollutants) and the electrochemical bioremediation (Figure 4), or electrochemically enhanced self-purification, consists on electro-stimulating sedimentary microbes to degrade $\mathrm{OM}$ on-site, and beside produce electricity. Such process is considered sustainable because it eliminates the injection of expensive chemicals and reduces the energy cost as compared to other technologies [90]. Electro-bioremediation excludes the electro-kinetic techniques (electrochemical transport or transfer of compounds) exclusive purpose of the Reddy \& Camselle's book "Electrochemical remediation technologies for polluted soils, sediments and groundwater" [91]. The major drawback of these techniques is the needs of electricity injections: MFC to power the pumps, and MEC to drive the non-spontaneous reactions [92]. These technologies cannot be simply scalable up to continuous field applications. They require a pump-\&-treat approach, easy at laboratory scale, a little bit more difficult at pilot or industrial scale. So, depending on the configuration chosen, they require the installation of a single or double chambered device, including a proton permeable membrane, many tanks and circulating pumps. They are energy intensive technologies, and large part of the electricity produced by the MFC is consumed in the pumping [93] [95]. Moreover, the application of weak electric fields can have negative effects on the OM degrading biofilm. Indeed, when a direct-current is applied to the sediment, the electrolysis of pore water occurs at both electrodes, and leads to $\mathrm{pH}$ changes at the cathode, and to the release of toxic reactive oxygen or chlorinated species with antimicrobial effects in the anode vicinity [96].

Generally, $\mathrm{OM}$ is the electron donor in bioremediation processes in polluted environments. Acceleration of self-purification based on metabolic activities of

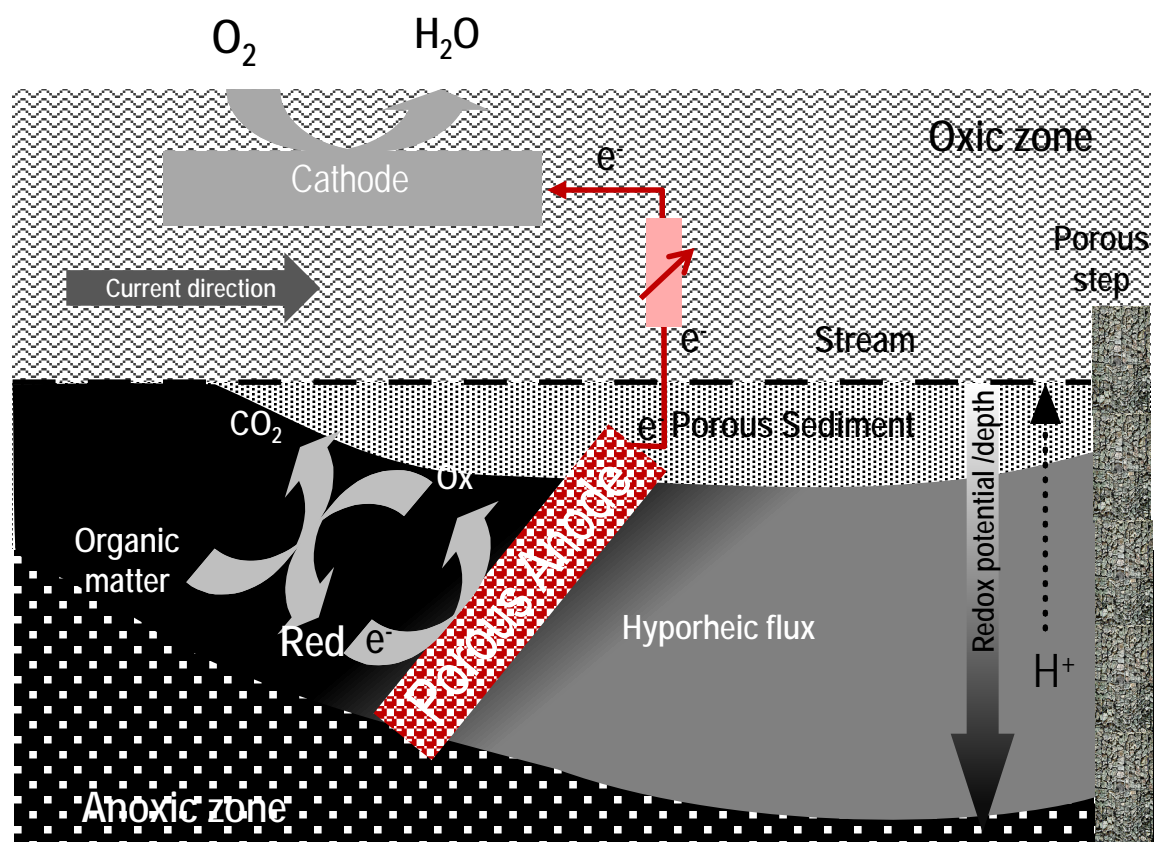

Figure 4. Schematic representation of the electrochemical bioremediation concept. 
natural sedimentary microorganisms is a widely accepted durable solution in environmental engineering, but its relatively low efficiency and delicate control considerably limit its actual application. A faster electron transfer to more conductive anode is assumed lead to sizable increase in OM oxidation rate, compared with natural electron acceptors [97]. Microorganisms in freshwater sediments seem preferred for degradation of PAHs to use the SMFC anode over added electrons acceptors as Fe(III) oxides [98]. SMFC could effectively stimulate bioremediation in anoxic conditions [10] [99]. Although still in the laboratory prototype stage, it has many potential advantages for controlled stimulation of bioremediation processes, with an environmental impact considered a priori relatively benign, but still needs to be clarified.

Even if the redox potentials shown in Figure 2 are approximate due to the influence of $\mathrm{pH}$, it obviously shows the existence of a window of redox potentials, which can be exploited to a smart electro-stimulation of the bioremediation. Introduction of an inexhaustible electron acceptor anode, a respiratory aid enabling bacteria equipped with the required metabolic system to breathe at the oxygen potential even within a fermentation medium. The selection of anode-respiring bacteria depends on the anode potential, which determines the amount of energy available for bacterial growth and maintenance [100], imparting a selective advantage to bacteria suitable to anode potential to synthesize more ATP than the methanogenic ones and increase their activity of oxidative degradation of the organic matter over competing functional groups as methanogens [101].

As the natural redox potential difference between oxygenated superficial water and anoxic sediments is generally $\approx 800 \mathrm{mV}$, between 770 and $870 \mathrm{mV}$ [86] [102] [103] [104] [105], and the energy gain for the microorganisms is higher using electron acceptors with a more positive potential, thus it is reasonable to hypothesize that a more positive anodic potential can enhance OM oxidation. Additionally by properly imposing the potential between $0 \mathrm{mV}$ and $100 \mathrm{mV}$ (NHE), it can be possible stimulate bio-remediation, while avoiding the formation of $\mathrm{H}_{2} \mathrm{~S}, \mathrm{CH}_{4}$ and $\mathrm{N}_{2} \mathrm{O}$. Indeed, anode respiring bacteria competing with methanogens on organic carbon sources have half-saturation coefficients (Ks) for acetate much lower than methanogens: e.g. Geobacter sulfurreducens: $10 \mu \mathrm{M}$ [106] versus Methanosaetaceae: $169 \mu \mathrm{M}$ and Methanosarcinaceae: $3.4 \mathrm{mM}$ [107]. Although we do not know whether this sensitivity difference is true for all methanogens, many studies have found that SMFCs can reduce $\mathrm{CH}_{4}$ [108].

The electro-bioremediation development is not only possible but desirable for its advantages. Firstly, it stimulates the contaminant removal without require neither chemical addition nor energy input, so the operational cost can be significantly lower than other remedial methods; moreover, it produces electrical current, which can power a remote monitoring device, and finally it is presumed lead to higher treatment efficiencies than with conventional biological processes [69] [94] [109]. 


\section{Materials and Design}

The construction and analysis of BMFCs requires thorough knowledge in separate scientific and engineering fields, ranging from microbiology and electrochemistry to materials and environmental engineering [81]. Obviously, the different materials and methods used to construct MFCs, techniques used to analyse their system performances, are transferable to BMFC, so the reviews dealing with MFCs constitute a major source of information [14]. The two main parts to consider are: the electrodes; and the overall connection and setup design, including collected electron management.

\subsection{Electrode Materials}

In BMFC the anode is in charge of collect the microbial respiration electrons; therefore, anodic materials must be conductive, chemically stable and non-hazardous in environmental conditions, and high degree of biocompatibility to all avoid any toxic effect upon the microorganisms. In BMFC the cathode is in charge to waste the anode electrons by reducing oxidized compounds. Oxygen is the most suitable electron acceptor because of its high oxidation potential, availability, low cost, sustainability, and the lack of any chemical waste production (water is the sole waste). The cathode must obviously have the same properties as the anode, but furthermore, the need to float on the water surface in order to maximum benefit of the oxygen concentration in air, imposes light and porous cathode materials, to facilitate oxygen access. So, soft carbon-based materials (felt, fabrics) stretched over resistant stainless steel frame or supported by polystyrene floats [110] are attractive solutions. To meet the above mentioned requirements anode and cathode can be made of metal, stainless steel or various carbon-based materials.

\subsubsection{Metal Electrodes}

Obviously electrodes made of $\mathrm{Cu}$ must be prohibited, due to the high toxicity of $\mathrm{Cu}^{2+}$ to microorganisms, but some noncorrosive metal electrode as stainless steel mesh or titanium can be utilized [84]. Stainless steel is an attractive material to create large electrodes for BES, due to its low cost, high conductivity and easy to install in the sediment due to its good mechanic strength, but the relatively small specific surface area and sensitivity to corrosion in anoxic environment makes it less suitable as anode material. Many stainless steels also undergo corrosion, but careful selection of chrome content apparently can produce materials stable even in seawater, but the maximum power density was only $4 \mathrm{~mW} / \mathrm{m}^{2}$ [84]. A power density only $0.8 \mathrm{~mW} / \mathrm{m}^{2}$ at the current density of $0.035 \mathrm{~A} / \mathrm{m}^{2}$ were achieve with a anode made of stainless steel fibre felt [111]. stainless steel foam could be more performing materials, the current density obtained $\left(80 \mathrm{~A} / \mathrm{m}^{2}\right)$ was 4 times and 2 times higher vs. plain stainless steel $\left(20 \mathrm{~A} / \mathrm{m}^{2}\right)$ and classic carbon cloth $\left(33 \mathrm{~A} / \mathrm{m}^{2}\right)$ respectively [112]. However, poor biocompatibility limits stainless steel successful application today, also a simple and effective method can make biocompatible stainless steel felt electrodes by iron oxide nanoparticle generation on the 
anode surface by means of flame oxidation (coating with hematite $\left(\alpha-\mathrm{Fe}_{2} \mathrm{O}_{3}\right)$ nanostructures). The flame oxidation multiplies by 16.5 the maximum current density, relative to the non-oxidized felt [113]. Tungsten carbide anode allows a maximum power point of $5.85 \mathrm{~W} / \mathrm{m}^{2}$ at a current density of $1.6 \mathrm{~mA} / \mathrm{cm}^{2}$, from a soil bacterial solution [114]. Uncoated titanium seems unsuitable as anode material [115] as gold in lab MFCs. Geobacter sulfurreducens produces at a flat conductive gold anode a current density of $688 \pm 160 \mathrm{~mA} / \mathrm{m}^{2}$ [116].

\subsubsection{Carbon-Based Electrodes}

Carbon-based electrodes are the most widely used in MFCs studies. Except non electrical conductive diamond (sp3 carbon), all the allotropic forms of carbon (amorphous carbon, glassy carbon, graphite, graphene and nanotubes) are used with various designs as electrode materials. Graphite plate anodes have been commonly adopted in early BMFC designs but they are difficult and costly to bury into the sediment. Graphite rod is more easily inserted than plate, but it presents relatively low surface area. Carbone felts offer a large colonization surface to bacteria, but are more difficult to install in sediments. Hence, selection of electrode material and design of its structure need special attention. In a synthetic review, Guo et al. (2015) examine impact on microorganism-electrode exchanges and electron transfer mechanisms of electrode surface topography and chemistry, and propose three relevant impact class at different scales [117]:

1) Adherence of the cells;

2) Formation and structure of the electroactive biofilm;

3) Electrical connectivity between the cells and the electrode in a direct or indirect ways.

Because of its excellent electrical conductivity and chemical stability, the graphite (graphite rod, plate or sheet and graphite fibre brush) is one of the most commonly used electrode materials [14] [118] [119], but for cost saving, practical applicability and efficient performance, carbon based electrodes are being used viz. carbon cloth, carbon felt (CF), carbon foam or paper, granular activated carbon (GAC) [120], reticulated vitreous carbon (RVC).

In terms of configuration, Wei et al. (2011) divided carbon-based electrodes into plane, packed, and brush structures [119]. We propose a simpler electrode classification, by sorting the electrode in two classes: 2D electrodes (carbon paper, graphite plates or sheets, and woven carbon: mesh or cloth) and 3D electrodes (organized carbon felts or cloths, corrugated carbon (from carbonized cardboard [121]) or granular forms), according their potential microbial exchanges and in-field implementations. Efforts focus on the design and structuring of the electrodes providing the largest active surfaces. In MFC, the anode is the limiting factor and the optimization of the anode projected area increases the power density [122]. Thin, but porous graphite or carbon displays the best conductive properties with lower cost and excellent biocompatibility.

3D structures are of particular benefit because they provide large available surface areas for bacterial colonization and substrate transport, solid and 
macroporous structures for redox reactions, electron transfers. One way to increase the surface area free to bacteria is the use of loose granular materials, such as granular graphite, or activated carbon, is one possible way. GAC electrode can be designed as a diffuse electrode, distributed into the sediment in order to develop a maximum contact surface with the sediment bacteria. Packed into a polypropylene mesh bag, GAC is inserted into sediment [123] and graphite rods are usually used to collect electrons from dispersed GAC in sediment. For a same material, small granules $(0.25-0.5 \mathrm{~mm})$ give a higher current density than larger granules $(1-5 \mathrm{~mm})$. More, for the same size, granules with a rough surface have a better performance than smooth ones [120]. The main question is: What is the optimal amount of given diameter granules to mix with sediment in order to have a high probability of connections between the granules?

Activated carbon felts have exceptional properties as a high electronic conductivity, low weight, good chemical stability, and low cost. However, the study of their intrinsic properties is a bit difficult due to their hydrophobicity and compressibility [124]. But above all they offer to bacterial growth loose texture and large surface areas, higher to carbon cloth and graphite sheets, but the bacteria growth is more likely to be restricted by the mass transfer of substrate and products inside electrode. Carbon felt and granular anode obtain similar current densities, but felt materials require around 30\% less material. In order to increase the available surface area for bacteria, the felt can be cut into cubes. Carbon and graphite felts are processed respectively at $1100^{\circ} \mathrm{C}-1800^{\circ} \mathrm{C}$ and $2200^{\circ} \mathrm{C}$ - $2600^{\circ} \mathrm{C}$. Two kinds of carbon felt precursors exist: Polyactylonitrile (PAN) and Rayon. Rayon carbon felt is cleaner and no lose fibres compared to PAN carbon felt. The carbon and graphite felt has the following peculiarities:

- high porosity (99\% if uncompressed material);

- great compressibility which makes it difficult to reproduce a constant electrode quality upon replacement in device;

- Variable electrical conduction through carbon/carbon or graphite/graphite contacts, depending on the contact strength. Indeed, felts are made of short fibres, $\approx 10 \mathrm{~mm} \varnothing$, and giving an exceedingly large number of contacts fibre to fibre. Also, the overall electrical conduction pattern is complex, depending on the degree of compression.

More elaborated nano-structures can be used, as carbon multiwalled nanotubes or carbon nanopowder immobilized in conductive adhesive on electrode surface [125]. The high performances of 3D carbon sponges consisting of interconnected carbon nanotubes, are due to excellent charge transfer between carbon nanotubes and microbes owing to 13 times lower charge transfer resistance compared to carbon felt [126]. Carbon fibres can be implemented in form of brushes, made of extruded graphite fibre $(7.2 \mu \mathrm{m} \varnothing)$ wrapped around one or more conductive corrosion-resistant metal wires like titanium wire [127] [128]. Carbon brush presents thousands of well-structured carbon fibres per $\mathrm{cm}^{2}$ to generate high surface area. Carbon felt or organised carbon fibres (e.g. carbon brush) have an overall superior performance in terms of current density per 
amount of involved anode material, but the mechanic strength (too soft and flabby fibres) and fragile structures of carbon brushes can be an issue of concern for long-term operations in benthic systems.

\subsubsection{Surface Functionalisation}

Electrode surface chemistry impacts the microbe-electrode interactions by many ways: 1) surface charge attraction; 2) hydrogen bonding; 3) van der Waals force; 4) immobilized mediator; 5) random roughness; 6) oriented nano-pattern and nanoparticles; and 7) hydrophilic properties of electrode surface, fostering a fast bacterial adhesion onto the electrode surface. Electrochemically active microorganisms attach preferentially on hydrophilic and positively charged surfaces [129]. Bacterial cells have a net negative charge on the cell wall, although the magnitude of this charge varies from strain to strain. Also, negatively charged groups at the electrode surface (carboxylate) decreased microbial fuel cell power output while the introduction of positively charged groups doubled the power output [130]. Hydrophilic functional groups can be added by thermal treatment, depending on the gas atmosphere (e.g., $\mathrm{N}_{2}, \mathrm{O}_{2}, \mathrm{NH}_{3}$ ) used. Carbon mesh heating $450^{\circ} \mathrm{C}$ for $30 \mathrm{~min}$ gives a maximum power density of $922 \mathrm{~mW} / \mathrm{m}^{2}\left(46 \mathrm{~W} / \mathrm{m}^{3}\right)$, $3 \%$ higher than a carbon mesh anode only cleaned with acetone $\left(893 \mathrm{~mW} / \mathrm{m}^{2} ; 45\right.$ $\mathrm{W} / \mathrm{m}^{3}$ ), but $7 \%$ less than carbon cloth treated by a high temperature ammonia gas process $\left(988 \mathrm{~mW} / \mathrm{m}^{2} ; 49 \mathrm{~W} / \mathrm{m}^{3}\right)$ [131]. Among the 3 different treatment methods examined to enhance power generation of carbon fibre brushes: 1) oxidizing acid treatment (200 g/L $\left(\mathrm{NH}_{4}\right)_{2} \mathrm{~S}_{2} \mathrm{O}_{8}$ in $\left.\left.100 \mathrm{~mL} / \mathrm{L} 98 \% \mathrm{H}_{2} \mathrm{SO}_{4}, 15 \mathrm{~min}\right) ; 2\right)$ heating $\left(450^{\circ} \mathrm{C}\right.$ for $\left.30 \mathrm{~min}\right)$; and $\mathrm{c}$ ) a combination of both processes. The combined heat and acid treatment improve power production to $1370 \mathrm{~mW} / \mathrm{m}^{2}$, which is $34 \%$ larger than the only acetone cleaned control $\left(1020 \mathrm{~mW} / \mathrm{m}^{2}\right)$. This power density is $25 \%$ higher than using only acid treatment $\left(1100 \mathrm{~mW} / \mathrm{m}^{2}\right)$ and $7 \%$ higher than that using only heat treatment $\left(1280 \mathrm{~mW} / \mathrm{m}^{2}\right)$. Analysis of the acetone cleaned or heated surfaces showed these processes decreased atomic $\mathrm{O} / \mathrm{C}$ ratio, indicating removal of contaminants that interfered with charge transfer [131]. The acid $\&$ heat treatment of the carbon fibre brushes increases by $60 \%$ the atomic ratio N/C (0.0261) compared to the acid treatment alone and the acetone cleaned control [132]. Adding protonated amine groups (from 0.38 to 3.99 meq. $\mathrm{m}^{2}$ ) by heat and $\mathrm{NH}_{3}$ treatments, can increase the $\mathrm{N} / \mathrm{C}$ ratio, amine group content, including $\mathrm{C}-\mathrm{N}$ and $\mathrm{C}=\mathrm{N}$, and the adhesion of negatively charged bacteria and enhances electron transfer between the bacteria and the carbon [133]. Dimethylaniline functionalization of carbon cloth electrode demonstrated that a low nitrogen addition enhances electric performance. Indeed N/C ratio of 0.7 achieved the highest power density $\left(938 \mathrm{~mW} / \mathrm{m}^{2}\right), 24 \%$ greater than an untreated anode. However increase N/C ratio to 3.8 lowers the power density to $707 \mathrm{~mW} / \mathrm{m}^{2}$ [134]. These results show that low-cost heat-treated carbon mesh materials can be used as anode, providing good performance, and even exceeding the carbon cloth anode performances. Coating 3D macro-porous anodes by with Nafion solution of various carbon nanoparticles (graphene, carbon nanotube, 
or activated carbon) on stainless steel fibre felts gives an open, solid and macro-porous structure, providing large surface area electrodes for reaction, interfacial transport and biocompatible interface available for bacterial colonization and substrate transport. Graphene modified anode delivered a maximum power density of $2142 \mathrm{~mW} / \mathrm{m}^{2}$ at a current density of $6.1 \mathrm{~A} / \mathrm{m}^{2}$, greatly improved compared with the unmodified stainless steel fibre felts [111]. Because of this natural 3D structure, carbon felt seems the better support for immobilization of multi-wall carbon nanotube (MWCNT). Indeed, Nitrate reduction efficiency was about $83.6 \%, 79.6 \%$ and $64.0 \%$ for MWCNT/carbon felt, MWCNT/carbon cloth and MWCNT/graphite cathodes, respectively [135]. Electron redox mediators immobilization on the anode surface could be an efficient method to improve the transfer of extracellular electrons and hence to boost power output. Various treatments ( $\mathrm{Co}$ and $\mathrm{Fe}-\mathrm{Co}$ tetra-methoxyphenyl porphyrin (FeCoTMPP) and platinised carbon and titanium) on carbon sponge, cloth and paper, graphite and reticulated vitreous carbon (RVC) were investigated with a graphite cloth as anode. Relatively low cost cathodes (carbon sponge and carbon cloth) gave power densities $\approx 30 \mathrm{~mW} / \mathrm{m}^{2}$. The FeCoTMMP modified cathode gave power density of $62 \mathrm{~mW} / \mathrm{m}^{2}$ which was nearly twice that achieved with the best un-modified carbon [136]. Chemical catalysts such as Pt and tetra-methoxyphenyl porphyrin are usually spread on the cathode surface to increase redox reaction kinetics especially when surface cathode must stay small size, but these expensive chemicals must be ban from water environment and for the majority of environmental applications the natural development of phototrophic biofilms on the cathode (biocathode) is enough to effectively catalyse redox reactions [137] [138]. Plain graphite anode functionalizing with quinone groups; graphite-ceramic composite containing $\mathrm{Mn}^{2+}$ and $\mathrm{Ni}^{2+}$; and graphite modified with a graphite paste containing $\mathrm{Fe}_{3} \mathrm{O}_{4}$ or $\mathrm{Fe}_{3} \mathrm{O}_{4}$ and $\mathrm{Ni}^{2+}$ showed between 1.5-fold (1,4-naphtho-quinone-modified graphite) and 2.2-fold (graphite-ceramic composite and graphite paste) greater kinetic activity than plain graphite [139]. The use of $\mathrm{MnO}_{2}$ on carbon cloth tested as alternative to cathodic catalysts as platinum $(\mathrm{Pt})$ suggests that using $\beta-\mathrm{MnO}_{2}$ instead of Pt could potentially lowering production cost [140] and decreases the start-up period by $30 \%$ versus a non-treated one [141]. Immobilization on the surface of electron redox mediators such as neutral red [142] also boosts the electron transfer. Neutral red was considered as one of the ideal mediators for anodes as it possesses a redox potential of $-325 \mathrm{mV}$ vs. NHE, which is rather close to the $-320 \mathrm{mV}$ (NHE) of $\mathrm{NAD}^{+} / \mathrm{NADH}$ couple [142]. Coating the surface of stainless steel-felt anode with hematite $\left(\alpha-\mathrm{Fe}_{2} \mathrm{O}_{3}\right)$ nanostructures [113] or carbon nanotubes [111] dramatically enhances the anode biofilm formation and thus the bioelectric-activity on stainless steel-felt. Photoelectrons from rutile $\left(\mathrm{TiO}_{2}\right)$ anode could be used by contaminant-degrading bacteria at a cathode, resulting in substantially increased current generation and bacterial growth. This finding implies a potential to utilize the high-energy photo-charges for assisting the BMFC remediation. Compared to an anode made of bare carbon felt, electrodeposition of $\mathrm{MnO}_{2}$ promotes 
MFC's power efficiency: the anode capacitance improved 46 times, and the maximum power density by $25 \%$ [143]. Note, that in sediment some natural occurring shuttles such as humic substances, or redox couples as $\mathrm{Fe}^{2+} / \mathrm{Fe}^{3+}$ and $\mathrm{Mn}^{2+} / \mathrm{Mn}^{3+}$ can transfer electrons between anode respiring bacteria and the anode. However, the conductivity and biocompatibility of carbon-based materials still offer enough room for progress. And indeed, many attempts aim at modify their surfaces in order to give more efficient anode materials, mainly for power generation.

\subsection{Design of Electro-Bioremediation Devices}

\subsubsection{Anode-Cathode Spacing}

A huge fraction of the ohmic loss in BMFC is caused by the electrode spacing. Unlike laboratory cells where chambers are only separate by thin membrane and electrode spacing can be easily reduced, in BMFC, limits exist due to the natural spatial separation existing between sediment oxic and anoxic zones. The best depth to embed anode in sediment should relatively shallow, between $3 \mathrm{~cm}$ [138], $5 \mathrm{~cm}$ [139] and $10 \mathrm{~cm}$ [82] below the sediment water interface, just under the oxic/anoxic transition interface. A deeper level leads to lower results due to a larger internal resistance. However, in some articles, despite the internal resistance increase, the power and current density from the anode at $-10 \mathrm{~cm}$ in sediment, were respectively 2.2 and 3.5 times higher, than those from the anode at $-2 \mathrm{~cm}$ [144]. Among the three anode-cathode spacing tested (15; 30 and 45 $\mathrm{cm}$ ) in pilot planted with Typha latifolia, the highest power density (36.48 $\mathrm{mW} / \mathrm{m}^{3}$ ) was achieved for $30 \mathrm{~cm}$ electrode spacing, despite a larger internal resistance equal to $430 \Omega$. But the pilot was fed by up-flow, so the results can explain by deficient fuel supply at the $15 \mathrm{~cm}$ anode [145]. In constructed wetland pilot made of gravel layers, anaerobic sludge and Phragmites australis, a $20 \mathrm{~cm}$ space between the electrodes give an optimal removal of chemical oxygen demand of $94.90 \%$ with a $0.15 \mathrm{~W} / \mathrm{m}^{3}$ power density, $339.80 \Omega$ internal resistance [146]. In fact it seems that there is no anode optimum depth, we must balance between the internal resistance and the anodic environment which must be both thermodynamically and kinetically favourable to electrode-reducing bacteria. Both electricity generation and pollutant removal increases when the anode-cathode interval decreases and in an interval range between $4 \mathrm{~cm}$ and $10 \mathrm{~cm}$, the more the electrodes are close, the more efficient the electricity generation and pollutant removal become [147]. In the field, the electrode spacing seems not so crucial. Results from a sensing probe (graphite anode embedded within a sand pack) for monitoring in situ microbial activity in an aquifer undergoing bioremediation, shows that MFC can produce detectable currents despite long range separation $(6 \mathrm{~m})$ between anode and cathode [148]. To overcome spacing issue, several setups are proposed as: tubular setup where the electrodes are separated only by a low-cost cloth and so the cathode catalytic surface (conductive paint + catalyst) inside the tube is directly exposed to air to allow efficient oxygen reduction; or 3D setup with multilayer or honeycomb anode structure. 


\subsubsection{Tubular Devices}

Tubular-type BES is constructed by winding together the anode, separator, and cathode layers around a perforated PVC tube, with the cathode facing inside and exposed to air, and the anode exposed to the surrounding matrix [13] [149] [150] [151]. Tubular BMFCs have been reported to decrease by about $33 \%$ the organic content in sediment [149], its application to contaminated sediments, increases the natural biodegradation by nearly 12 fold [152], and for treating petroleum hydrocarbon in waterlogged soils, it is an easy technology to implement at lab scale, that significantly reduces device internal resistance, improves mass transfer, facilitates cathode $\mathrm{O}_{2}$ reduction, and stimulates efficient functional microbial communities [150].

U-tube BMFC consists in an air-cathode placed inside the anode chamber and had been proven to be efficient for electricity recovery due to the low internal resistance [153]. Its use increases petroleum hydrocarbon removal by $120 \%$, from $6.9 \%$ to $15.2 \%$ close to the anode $(<1 \mathrm{~cm})$, for waterlogged saline soil but the yield falls with distance and water content [154].

Snorkel BMFC consists in a single conductive tube (snorkel) properly set to create an electrochemical linking between the anoxic zone (polluted sediment) and the oxic zone (superficial oxygenated water). The lower part is buried within sediment and plays the role of anode, accepting electrons from the organic matter oxidation. Electrons flow along the snorkel up to the part exposed to the aerobic environment (cathode part), where they reduce oxygen to form water [155]. Results of an over 400 day study in $120 \mathrm{~mL}$ serum bottles show an increase of oxidative reactions in the marine sediment tested with a significant reduction in total petroleum hydrocarbons (TPH) content of $12 \% \pm 1 \%$ and $21 \% \pm$ $1 \%$ in pilots with one and three snorkels, respectively [156].

\subsubsection{Multi-Layer Anode Devices}

Another major concern in electro-bioremediation field-scale application is the low ratio between the limited volume under anode influence and the large sediment volumes to be treated. Indeed, with a conventional BMFC, the affected sediment radius by anode is very narrow, typically about few centimetres around the anode [102] [151] [154] to several tens of $\mathrm{cm}$ according the number of operating days [151]. To extend the anode influential area some new system setups were proposed such as multi-anode setup. It consists in linking several smaller-sized anodes instead of one big anode, to achieve segmented anode arrays. Indeed some laboratory results from SMFC using a fabric anodes on seafloor indicate that power generation scales almost linearly with anode size up to about $1-2 \mathrm{~m}^{2}$ of projected surface area, larger anodes suffer reduction in power density, suggesting that the majority of losses along the anode surface occur closest at the connecting wire, where the amount of current is the greatest [157]. The use for 180 days of three layers of $3 \mathrm{~cm}$ spaced anodes with an activated carbon cathode, accelerates degradation both polycyclic aromatic hydrocarbons (PAHs) and n-alkanes in each layer compared to the open control et yields a net 
degradation rates of TPH, 16 priority PAHs and total $n$-alkanes of $18 \%, 36 \%$ and $29 \%$, respectively [158]. The anode spatial configuration (horizontal or vertical) appears to affect the biodegradation yield: the horizontal anode setup removes up to $12.5 \%$ of TPH after 135 days, $50.6 \%$ more than the vertical setup (8.3\%) and $95.3 \%$ more than the open circuit setup (6.4\%). The lower mass transport resistance in the horizontal setup than in the vertical one seems to result in more power and more TPH removal [159]. Multiple anode SMFCs seem generate more electricity, and in more sustainable way due to increased anode surface area, while anode distance have limited effects on overall system performance, as show a 3D anode (carbon mesh on a $10 \mathrm{~cm}$ height 'honeycomb' structure) full covered with river sediments [160].

\subsubsection{Power Management System}

BMFC scaling-up do not consist in its size rising, as any increasing of electrode surface area results in decreased power density. As alternative to the physical scale-up of BMFCs, it is possible to scale up power by using smaller-sized BMFCs operating alone connected to a power management system and managed them in such way to maintain a sufficiently low redox potential for a total denitrification up to $\mathrm{N}_{2}$, and/or a full anammox, resulting in no accumulation of $\mathrm{N}_{2} \mathrm{O}$, but without reaching the potential formation of $\mathrm{H}_{2} \mathrm{~S}$ and $\mathrm{CH}_{4}$.

Classical electrical circuit includes voltage meters (or a potentiostat to a finer understanding of the system) connected in parallel to properly measure cell voltages and potentials between electrodes. The current is calculated as a function of the voltage ( $U$, Volt) and the external resistance $(R, \mathrm{Ohm})$ according to Ohm's law, $I=U I R$. A potentiostat can also operate in a two-electrode setup to obtain polarization curves or to determine the ohmic resistance of the MFC with the current interrupt method. The power output $(P$, Watt) is calculated according to $P=U I$. The potentials of anode and cathode electrodes were measured according to a reference electrode of $\mathrm{Ag} / \mathrm{AgCl}$ in a three electrode setup [81]. In a MFC, the highest observed potential when the circuit is open (infinite resistance, zero current) is around $800 \mathrm{mV}$. When the circuit is closed, electrons flow from anode to cathode, and the potential decreases as a result of voltage losses depending on the load. The anode and cathode interfere with each other: any voltage reduction at one electrode increases the voltage at the other one. This fact is attributed to the reactant/product concentration gradients existing between the cathode and its surrounding medium, and between biofilm and the anode surface [161].

$\mathrm{CH}_{4}$ production and anode potential are linked, suggesting the anode potential influences the competition between anode respiring bacteria and methanogens for substrates [101]. It exists an optimal anode potential around $-200 \mathrm{mV}$ vs $\mathrm{Ag} / \mathrm{AgCl}(\approx 0 \mathrm{mV} / \mathrm{Eh})$, which regulates both the activity and growth of anode respiring bacteria [97]. This potential allows the anode respiring bacteria to synthesize more ATP than the methanogenic ones and increases their oxidative degradation activity of $\mathrm{OM}$ to the detriment of the methanogenic activity. The 
ability to control the anodic microbial activity by action on the potential is well established, but unfortunately, the performance criterion used is always the power production and not GHG production [68] [93] [97] [162] [163] [164] [165]. So, if not properly managed, a MFC running can product a significant amount of GHG. The electro-bioremediation management is little bit different than in case of energy production, it is not matter maximum extracting of electrons but to fine tune anode potential to favour anode respiring bacteria and ban methanogen activity. The BMFC bioremediation overall working must be assessed according to substrate oxidation rate and issuing reduced products $\left(\mathrm{N}_{2}\right.$, $\mathrm{CH}_{4}, \mathrm{H}_{2} \mathrm{~S}$ ). In electro-bioremediation the voltage must be poised at a proper potential, by means of variable resistor box, but this cannot be continuously done and it is times consuming. Operate BMFCs continuously at a constant poised potential during real-life conditions requires the use of an expensive multichannel potentiostat. However, by monitoring the anode potential, variable resistor can be tuned allowing operating at a desired potential around $-200 \mathrm{mV}$ vs $\mathrm{Ag} / \mathrm{AgCl}$ [97]. The anode potential is affected by three major types of losses that can be identified on a polarization curve [81]:

1) Starting from the open circuit voltage at zero current, there is an initial steep voltage decrease: the activation losses dominate and redox reaction kinetics is limiting. Anode respiring bacteria can lower this overpotential by optimizing their electron-transfer strategies and thus increase their own metabolic activity. These interactions between biomass and anode are related to the anode surface properties;

2) Then the voltage falls more slowly, fairly linear with current: the ohmic losses dominate, due to ion transfer. Porewater $\mathrm{H}^{+}$and cations flowing toward the cathode, faces a resistance adding ohmic losses in sediment. Additionally, the anode resistance (materials and connexions) introduces an ohmic voltage loss and hampers the electron flux. The highest currents ensure the highest rate for OM oxidation. But generally in-field BMFC suffers from high over-potential, especially in freshwater milieu where porewater conductivity is low;

3) Finally, at higher currents the voltage rapid falls: there the mass transfer losses dominate, due the reactions at the electrodes are limited by the ability of the reactants and products to move toward and away from the electrode. For a maximum self-purification, the substrate supply in sediment should be at least equivalent to the electron extraction capacity of the anode. The anode design is an important factor to avoid any anode saturation. The $\mathrm{H}^{+}$diffusion resistance through sediment and biofilms results in local $\mathrm{pH}$ increase which may adversely affect bacterial physiology and thus self-purification processes. Another possible way to reduce the mass transfer losses is to increase the anode contact areas with the sediment. But this raises the ohmic losses due to increased current flow and to a dissimilar distribution of potentials. These problems are less important at the cathode as with floating cathode, rapidly colonized by bacteria, and where oxygen concentration is saturating [139] [166]. 
Theoretically, a BMFC can directly feed its power management system (PMS), but two main obstacles must be overcome: 1) the production of a low potential of $\max 0.8 \mathrm{~V}$, unusable as-is by most electronic devices requiring at last $0.9 \mathrm{~V}$ to $1.8 \mathrm{~V}$; and 2) the power production intermittence. Both particularities request a PMS able to stock and concentrate the harvested energy. To meet these requirements capacitors have been used to store harvested energy and then deliver it in short bursts of high-power to power sensors [86] [167] [168]. Ultra-low voltage PMS consist in a capacitor, a voltage comparator to repower the system, and a charge pump/DC-DC converter to boost the potential. Such setup operated for over a year to power a wireless temperature sensor [86] [167]. The sharing of output storage element in order to collect energy at higher voltage in a single capacitor avoids problems related to different working between BMFCs [169]. A BMFC-PMS system monitored and controlled by an "ultra-low-power microcontroller" chip (MSP430G2553, TI) can be designed, where the electron input is directly linked to an inductor-based energy harvesting circuit. When the metal oxide semiconductor field-effect transistor (MOSFET) switches on, the electrons flow and generated a voltage across the inductor. When the MOSFET switches off, the energy stored in inductor is transformed into electric current and flows through a Schottky diode into a capacitor. A lithium-ion battery is used as the terminal electricity storages [104]. The active power management using an "ultra-low power harvester" chip (BQ25505, TI) enhances the MFC system yield, compared to passive resistors, not only in the traditional maximal power point, but also other operating points such as the maximum current point and the maximum voltage point. Results show that active harvesting increases the maximal power point output by $81 \%-375 \%$ and the coulombic efficiency by $207 \%-805 \%$ compared with resistors at the same points [170]. Finally, if in the past decade, a large number of fundamental studies on SMFC have be done, paving the way for a growing variety of possible application domains, but because of their focus on energy production and not the redox potential control, among this abundant work, very few used a 3-electrode setup in on-site experiments, the only one ensuring well-controlled electrochemical conditions. Among them, a bacterial respiration study in Arctic peat soils, where a series of operational amplifiers has be used as biosensor, with a working poised at $+0.1 \mathrm{~V}$ (NHE), to mimic electron acceptors (as Fe[III], humic acids) or electron donors (as Fe[II]). The authors published an open-source, cost-effective and field-ruggedized three channel microcontroller-based potentiostat [171].

\section{Electro-Bioremediation in Water Bodies}

There are three test levels in electro-bioremediation studies: 1) bench tests in microbial fuel cells ( $<1 \mathrm{~L}$ volume); 2) pilot tests on well-equipped semi-industrial devices ( $>1 \mathrm{~L}$ volume) are usually small-scale field-tests and are essential before site implementation to optimize redox processes in BMFC. They constitute the majority of work on the setup merging constructed wetlands and MFC; and 3) 
field tests with quasi-industrial-scale projects. According to our classification the two first levels deal with SMFCs, and only the field studies concerns the BMFCs themselves. The voltage stabilization time can vary, depending largely on the size and complexity of the device. In bench tests the voltage stabilizes after about ten days: 2 - 3 days for marine sediment [138]; 10 days for a swamp sediment test [105] and Diesel-fed sludge MFC [172], 13 days for tidal mud test [173]; 22 days for waterlogged soil test [147]. In pilot tests the voltage stabilises after more time, about some tens of days: 35 days for a wetland pilot [174], a floating garden planted with Oryza sativa [169] and waste-contaminated river sediment pilot [104]; 40 days in wetland pilot planted with Typha latifolia [145]. In field experiments the voltage stabilization time is supposed longer.

\subsection{Bench Tests}

Allowing easier manipulations and testing, bench tests are performed on sediment samples from the natural site and studied into two-chamber cell, or vials for laboratory-scale runs. This study scale is often referred to as a microcosm study and focuses on the electro-biodegradation of contaminants such as pesticides [9] [175], and petroleum spills [12] [158] [172], and are also used to easily study and optimize some operational electrochemical parameters such as polarization curves, coulombic efficiency and activation, ohmic and transport losses.

\section{Contaminant Electro-Bioremediation Tests}

Pesticides and oil products are among the most common and harmful subsurface contaminants due to their extensive use, persistence in the environment, and toxicity. The microbiological processes, involved in bio-electrochemical remediation of recalcitrant pollutants, are currently not fully understood, particularly in relation to electron transfer mechanisms. Some reviews provide a comprehensive analysis of the research on bio-electrochemical remediation and of the key parameters involved in the process [9] [12] [172]. As show in Table 1, BMFC could boost the natural degradation activities of sediment microorganisms over a wide range of organic contaminants [77] [105] [152] [156] [176] [177] [178], and even inorganic species [179].

Lab-scale study of a diesel-fed MFC shows clear effects of the prior electrode enrichment on diesel removing from polluted groundwater (complete removal of diesel $800 \mathrm{mg} / \mathrm{L}$ within 30 days) and current generation, going from 15.04 $\mathrm{mW} / \mathrm{m}^{2}$ (without prior inoculation), to $90.81 \mathrm{~mW} / \mathrm{m}^{2}$. Therefore, a prerequisite step in electro-bioremediation should be a selective enrichment of the anodic electrode (bio-augmentation) to enhance its degradation capability [172]. Some results suggest that anode respiring bacteria can promote dechlorinating bacteria. Indeed, when the anode is poised at a sufficiently low potential, some anode respiring bacteria can give their electrons for the reduction of electrochemically more positive electron acceptors, rather than at the anode. Anaerobic bioremediation via reductive dechlorination could be an efficient technology for remediation 
Table 1. Summary of studies at the bench-scale and pilot-scale, dealing with the electrochemical bioremediation in sediments and waterlogged soils.

\begin{tabular}{|c|c|c|c|c|c|c|c|}
\hline Inoculum & MFC & Medium & Removal yield & $\begin{array}{l}\text { Anode } \\
\text { material }\end{array}$ & Regulation & Potential & Ref. \\
\hline $\begin{array}{l}\text { Natural } \\
\text { microbial } \\
\text { consortium }\end{array}$ & $\begin{array}{c}100 \mathrm{~mL} \\
\text { Single cell }\end{array}$ & $\begin{array}{c}\text { contaminated } \\
\text { marine sediment }\end{array}$ & $\begin{array}{c}24 \% \text { removal } / 66 \mathrm{~d} \\
\text { from } 16 \mathrm{~g} / \mathrm{kg} \text { total } \\
\text { petroleum } \\
\text { hydrocarbons }\end{array}$ & $\begin{array}{l}\text { carbon } \\
\text { cloth }\end{array}$ & $\begin{array}{l}1000 \Omega \\
\text { resistor }\end{array}$ & n.d. & {$[152]$} \\
\hline $\begin{array}{l}\text { Natural } \\
\text { microbial } \\
\text { consortium }\end{array}$ & $\begin{array}{c}\text { Snorkel in } \\
120 \mathrm{~mL} \\
\text { serum bottles }\end{array}$ & $\begin{array}{c}\text { artificially } \\
\text { contaminated marine } \\
\text { sediment (crude oil) }\end{array}$ & $\begin{array}{c}\text { Up to } 22 \% \\
\text { removal } / 200 \mathrm{~d}\end{array}$ & $\begin{array}{l}\text { Graphite } \\
\text { rods }\end{array}$ & n.a. & n.a. & {$[156]$} \\
\hline $\begin{array}{l}\text { Pure culture of } \\
\text { Geobacter } \\
\text { metallireducens } \\
\text { and } \\
\text { G. sulfurreducens }\end{array}$ & $\begin{array}{c}250 \mathrm{~mL} \\
\text { dual-chamber }\end{array}$ & River sediment & $\begin{array}{l}\text { reduce nitrate to } \\
\text { nitrite }\end{array}$ & graphite & $\begin{array}{l}\text { Potentiostat } \\
\text { poised }\end{array}$ & $-500 \mathrm{mV}$ & [179]. \\
\hline $\begin{array}{l}\text { Pure culture of } \\
\text { G. metallireducens }\end{array}$ & $\begin{array}{c}250 \mathrm{~mL} \\
\text { dual-chamber }\end{array}$ & $\begin{array}{c}\text { hydrocarbon-contaminated } \\
\text { harbour sediment }\end{array}$ & $\begin{array}{c}{\left[{ }^{14} \mathrm{C}\right] \text {-toluene }} \\
(\approx 90 \% \mathrm{removal} / 7 \mathrm{~d}) \\
\text { and }\left[{ }^{14} \mathrm{C}\right] \text {-benzene } \\
(\approx 35 \% \mathrm{removal} / 9 \mathrm{~d})\end{array}$ & $\begin{array}{l}\text { solid } \\
\text { graphite } \\
\text { stick }\end{array}$ & $\begin{array}{l}\text { Potentiostat } \\
\text { poised }\end{array}$ & $\begin{array}{c}+300 \mathrm{mV} \\
\text { (vs } \mathrm{Ag} / \mathrm{AgCL} \text { ) }\end{array}$ & [176]. \\
\hline $\begin{array}{l}\text { Pure culture of } \\
\text { G. lovleyi }\end{array}$ & $\begin{array}{c}250 \mathrm{~mL} \\
\text { dual-chamber }\end{array}$ & Synthetic growth medium & $\begin{array}{l}\text { Tetrachloroethene } \\
\text { removal rate: } \\
25 \mu \mathrm{mol} / \mathrm{d}\end{array}$ & $\begin{array}{l}\text { graphite } \\
\text { lectrode }\end{array}$ & $\begin{array}{l}\text { Potentiostat } \\
\text { poised }\end{array}$ & $\begin{array}{c}+500 \mathrm{mV} \text { or } \\
-300 \mathrm{mV} \\
(\mathrm{NHE})\end{array}$ & [180] \\
\hline $\begin{array}{c}\text { Mixed culture } \\
\text { dominated } \\
\text { by sulphate reducers }\end{array}$ & $\begin{array}{c}250 \mathrm{~mL} \\
\text { dual-chamber }\end{array}$ & $\begin{array}{c}\text { artificial sea water }+ \\
\text { hydrocarbon-contaminated } \\
\text { marine sediment }\end{array}$ & $\begin{array}{l}\text { Toluene } \\
\text { removal rate: } \\
\approx 1 \mathrm{mg} /(\mathrm{L} . \mathrm{d})\end{array}$ & $\begin{array}{l}\text { Graphite } \\
\text { plate }\end{array}$ & $\begin{array}{l}\text { Potentiostat } \\
\text { poised }\end{array}$ & $\begin{array}{c}+300 \mathrm{mV} \\
(\mathrm{Ag} / \mathrm{AgCl})\end{array}$ & {$[178]$} \\
\hline $\begin{array}{c}\text { Mixed } \\
\text { culture rich in } \\
\gamma \text {-Proteobacteria, } \\
\text { in mineral medium }\end{array}$ & $\begin{array}{c}320 \mathrm{~mL} \\
\text { single cell }\end{array}$ & $\begin{array}{l}\text { Anode biofilms } \\
\text { in artificial medium }\end{array}$ & $\begin{array}{c}93.5 \text { removal } \\
\text { from } 8000 \mathrm{mg} / \mathrm{L} \\
\text { within } 30 \mathrm{~d}\end{array}$ & $\begin{array}{l}\text { Carbon } \\
\text { fibre brush }\end{array}$ & $\begin{array}{c}\text { external } \\
\text { resistance } \\
\text { of } 1000 \Omega\end{array}$ & n.a. & {$[172]$} \\
\hline $\begin{array}{l}\text { Natural } \\
\text { microbial } \\
\text { consortium }\end{array}$ & $\begin{array}{c}\text { Snorkel, PVC } \\
10 \mathrm{~cm} \text { column, } \\
\text { granular coal filled, } \\
\text { stainless steel } \\
\text { mesh stopper } \\
(400 \times 400 \mathrm{~mm}) \\
\text { in sediment tank }\end{array}$ & $\begin{array}{l}\text { Swamp } \\
\text { sediment }\end{array}$ & $\begin{array}{c}8 \%-18 \% \\
\text { organic } \\
\text { matter } \\
\text { removal/120 d }\end{array}$ & $\begin{array}{c}\text { stainless } \\
\text { steel mesh }\end{array}$ & $\begin{array}{c}\text { No } \\
\text { poised }\end{array}$ & $200 \mathrm{mV}$ & [105] \\
\hline $\begin{array}{l}\text { Natural } \\
\text { microbial } \\
\text { consortium }\end{array}$ & $\begin{array}{c}2.5 \mathrm{~L}, 1.2 \mathrm{~m} \\
\text { cylinder } \\
\text { in PVC, } \varnothing 5 \mathrm{~cm}\end{array}$ & $\begin{array}{l}100 \mathrm{~cm} \text { organic-rich } \\
\text { sediment; and overlying } \\
\text { water from pond }\end{array}$ & & $\begin{array}{l}\text { stainless steel } \\
\text { bottle brush }\end{array}$ & $\begin{array}{l}1000 \Omega \\
\text { resistor }\end{array}$ & & {$[152]$} \\
\hline $\begin{array}{c}\text { Natural } \\
\text { microbial } \\
\text { consortium }\end{array}$ & $\begin{array}{c}3 \mathrm{~L} \text {, Tubular } \\
\text { MFC } \\
\text { PVC tube } \\
(20 \mathrm{~cm}, \varnothing 3.5 \mathrm{~cm})\end{array}$ & $\begin{array}{l}\text { Waterlogged diesel } \\
\text { and engine oil } \\
\text { contaminated soil }\end{array}$ & $\begin{array}{c}63.5 \%-78.7 \% \\
\text { removal } / 64 \mathrm{~d} \\
(37.6 \%-43.4 \% \\
\text { in open control })\end{array}$ & $\begin{array}{l}\text { carbon cloth } \\
\text { or biochar }\end{array}$ & $\begin{array}{l}100 \Omega \\
\text { resistor }\end{array}$ & & [151] \\
\hline $\begin{array}{c}\text { Natural } \\
\text { microbial } \\
\text { consortium }\end{array}$ & $\begin{array}{c}4 \text { L Plexiglas } \\
\text { column } \\
(35 \mathrm{~cm}, \varnothing 12 \mathrm{~cm})\end{array}$ & $\begin{array}{l}0-10 \mathrm{~cm} \text { depth } \\
\text { lake sediment }\end{array}$ & $\begin{array}{l}92 \% \text { benzo[a]pyrene } \\
\text { removal/970d } \\
(54 \% \text { in controls })\end{array}$ & $\begin{array}{l}\text { graphite } \\
\text { felt }\end{array}$ & $\begin{array}{l}100 \Omega \\
\text { resistor }\end{array}$ & $\begin{array}{c}132 \pm 24 \mathrm{mV} \\
(\mathrm{NHE})\end{array}$ & [77] \\
\hline $\begin{array}{c}\text { Concentrated } \\
\text { anaerobic } \\
\text { sludge from } \\
\text { WWTP }\end{array}$ & $\begin{array}{c}35 \mathrm{~L}, 50 \mathrm{~cm} \\
\text { cylinder } \\
\text { in polyacrylate, } \\
\varnothing 30 \mathrm{~cm}\end{array}$ & $\begin{array}{l}\text { Artificial constructed } \\
\text { wetland soil, } \\
\text { Ipomoea aquatica } \\
\text { planted }\end{array}$ & $\begin{array}{l}61 \% \text { brilliant red } \\
\text { X-3B dye } \\
\text { decolorisation/3d } \\
\text { hydraulic } \\
\text { retention time }\end{array}$ & $\begin{array}{c}\text { Granular } \\
\text { activated } \\
\text { carbone }\end{array}$ & $\begin{array}{l}1000 \Omega \\
\text { resistor }\end{array}$ & & {$[177]$} \\
\hline $\begin{array}{c}\text { Natural } \\
\text { microbial } \\
\text { consortium }\end{array}$ & $\begin{array}{c}\text { Water tank: } \\
390 \mathrm{~L}, \mathrm{~L}: 120 \mathrm{~cm} \text {, } \\
\text { 1: } 50 \mathrm{~cm}, \mathrm{~h}: 65 \mathrm{~cm}\end{array}$ & River sediment & $\begin{array}{c}74 \% \mathrm{PAH} \\
\text { removal/72 d }\end{array}$ & $\begin{array}{l}\text { Carbon mesh } \\
\text { on porous } \\
\text { honeycomb- } \\
\text { structure }\end{array}$ & $\begin{array}{l}10 \Omega \\
\text { resistor }\end{array}$ & $\begin{array}{c}150 \mathrm{mV} \\
(\mathrm{Ag} / \mathrm{AgCl})\end{array}$ & {$[160]$} \\
\hline
\end{tabular}


of organochlorine compounds as tetrachloroethene to cis-dichloroethene [180], trichloroethene [181], PCB 61 [182]. It relies on the capacity of anaerobic dechlorinating bacteria to "respire" organochlorine contaminants, using them as terminal electron acceptors in their energy metabolism. The finding paves the way to innovative bio-electrochemical systems based on direct extracellular electron transfer to dechlorinating bacteria. Therefore, BMFC can not only directly enhance sediment bioremediation through fine tuning the redox-dependent reactions but also by affecting the microbial dominance and activities.

\subsection{Pilot Tests}

\subsubsection{Bioremediation Studies}

The pilot tests aim at build more realistic field conditions than the bench tests. Microbial metabolism and community structure distinctively respond to the electro-bioremediation [150] [151]. In bucket of waterlogged soil hydrocarbon-contaminated, TPH removal rate almost doubled in soils across $34 \mathrm{~cm}$ radius from the anode $(63.5 \%-78.7 \%$ after 64 days and $82.1 \%-89.7 \%$ after 120 days) compared to $37.6 \%-43.4 \%$ in the open circuit. Analyses identified distinctive microbial communities at the anode. Uncommon anode respiring bacteria capable of hydrocarbon degradation such as Comamonas testosteroni, Pseudomonas putida, and Ochrobactrum anthropi were selectively enriched, while hydrocarbon oxidizing bacteria were dominant in soil samples. In a aquarium filled with $15 \mathrm{~cm}$ sediment layer, OM was decreased by $5.0 \%$ during the first 15 days of operation (Total decreased by $14.5 \%$ ), demonstrating good capability of simultaneous OM removal [160]. After 175 days of operation between $57 \mathrm{mV}$ and 271 $\mathrm{mV}$, in a $1 \mathrm{~L}$ SMFC, the removal rates of anthracene, phenanthrene, and pyrene were increased to $54.2 \% \pm 2.7 \%, 42.6 \pm 1.9 \%$ and $27.0 \% \pm 2.1 \%$ from $20.8 \% \pm$ $1.1 \%, 17.3 \% \pm 1.2 \%$ and $11.7 \% \pm 0.9 \%$, respectively, by the open SMFC, with an increasing factor of $161 \%, 146 \%$ and $131 \%$ respectively [147]. A decrease in OM water content from $40 \pm 2 \mathrm{mg} / \mathrm{L}$ to $19 \pm 5 \mathrm{mg} / \mathrm{L}$ was measured in a BMFC after the addition of synthesis wastewater, while the removal of (Benzo (b) fluoranthene, Benzo ( $k$ ) fluoranthene and Benzo (a) pyrene) in sediment samples reaches $74 \%$. Community analyses show a shift of anode community diversity with an abundance increase in Chloroflexi, Firmicutes and anode respiring bacteria like G. psychrophilus [183].

\subsubsection{Constructed Wetlands Pilots}

The merging of two nature-based technologies (constructed wetlands (CWs) and MFCs), is especially relevant since both are based on the microbial action to degrade wastewater contaminants. CWs are engineered water bodies planted with aquatic vegetation (macrophytes) designed to treating municipal or industrial wastewater or storm water runoffs. The biofilms associated to plant roots or to the bed filter material, are supposed to be the responsible for the degradation efficiency of CWs [64]. MFCs require the anode in anaerobic zones whereas the cathode needs oxygen; both redox conditions naturally occur inside CWs. For 
this reason, research into combining the two technologies has emerged in recent years to improve wastewater treatment capacity of wetlands and simultaneously producing electrical power [11] [108] [146] [184]. Unfortunately, as producing electricity seems currently the essential aim of published studies, all of them are operating under flooded conditions with a buried anode and a cathode at the surface and in the plant rhizosphere to maximize the redox gradient. Such conditions are propitious to production and emission of GHGs and are therefore no ecologically sustainable. Relatively less effort has been devoted to inhibiting methanogenic metabolism in the coupled MFC-CW system. $\mathrm{CH}_{4}$ emissions from MFC-CWs depend on: $\mathrm{CH}_{4}$ production in the anaerobic anodic zone; $\mathrm{CH}_{4}$ oxidation in the aerobic anodic zone; direct $\mathrm{CH}_{4}$ transfer via molecular diffusion and bubble ebullition across the water-air interface; and indirect $\mathrm{CH}_{4}$ transportation through vascular plants from the anaerobic zones to the atmosphere. As operating conditions of the MFC-CWs significantly affect methanogenesis. To maximize generation of electrical energy and inhibition of $\mathrm{CH}_{4}$ emission from MFC-CWs, electron flux must be fine-tuned. $\mathrm{CH}_{4}$ emission could be virtually suppressed $(\approx 98 \%$ ) with external resistance of $200 \Omega$, with an improved coulombic efficiency of $14.9 \%$ and current density of $187 \mathrm{~mA} / \mathrm{m}^{2}$ [185]. But electrobioremediation can also be merged with other mitigation approaches, such as:

- Incorporating selected plants could prevent $\mathrm{CH}_{4}$ and $\mathrm{N}_{2} \mathrm{O}$ production by the system [174]. The anodes of planted MFC, where living plant roots provide electron donor, via rhizo-deposition, to a mixed microbial community to generate electricity in a microbial fuel cell [186] and planted CW [187] offer a more favourable electron acceptor and limit the growth of methanogens;

- Smart hydraulic management can limit the GHG production in CWs. Management of hydraulic retention time, intermittent loading and pulsing hydrologic regimes have also been recommended [177] [187] [188] [189] and could be used together to manage MFC-CWs.

\subsubsection{Plant MFC and Paddy-Field Pilots}

A paddy field is a flooded parcel of arable land used for growing rice and other semiaquatic crops. As their $\mathrm{CH}_{4}$ emissions likely contribute about $9 \%$ of total global anthropogenic emissions [39], many studies deal with plant-MFC, called in this case paddy-field-MFC, where the anode is set in the rice paddy sediment prior to the rice planting and cathode on the sediment [90]. In these BMFC the rhizosphere microbes oxidize photosynthesized organic compounds excreted from rice roots, generating electrons that are immediately transferred to the anode. Electricity generation in these systems is thus dependent on the photosynthetic rate of rice plants, resulting in a circadian oscillation of the electric outputs. Paddy-field-BMCFs have demonstrated the potential of electricity generation for mitigating $\mathrm{CH}_{4}$ emission from the rhizosphere. Notably, however, the presence of large amounts of organics in the rhizosphere seems drastically reduces the effect of electricity generation on $\mathrm{CH}_{4}$ production [191]. 


\subsection{Field Implementation}

To our knowledge there is no effective full-scale implementation of electro-bioremediation on the field [9]. The two main current options in in-field applications of BMFCs are: the constructed wetlands with or without plants and its particular variant: the paddy-fields. Obviously, results from bench and pilot tests are used to guide full-scale design and implementation of actual electro-bioremediation setup. But any in-site BMFC configuration is unique and must be tailored according to the site features, such as: its geomorphology, pollutant load, hydraulic retention time, local water chemistry and meteorological conditions. Indeed the optimal design and deployment manners of BMFC are highly site-specific and need to be carefully assessed and tested [10]. Also, field data are still scarce and conflicting, very few studies deal with the installation of BMFC in real operational conditions in rivers, lagoons or ponds.

The first field setup designed to energy productions consist in two graphite or stainless steel electrodes positioned parallel $\approx 20-40 \mathrm{~cm}$ above and below the sediment-water interface is set up in marine environment [86] [102]. In order to alleviate the mass transfer limitations in sediment, reduce internal resistance and promote power generation, Nielsen et al. set up a benthic chamber above the sediment to house a $1 \mathrm{~m}$ long carbon brush anode. The chamber was intermittently fed by water pumping or by natural advection flow of interstitial water from sediment [192]. The setup produced power densities higher by an order of magnitude than those obtained by classical BMFCs with buried graphite plate anodes, proving that the exploitation of the natural hydraulic flows, when they exist, would significantly improve sediment mass transport. These setups demonstrate that a BMFC can be an effective renewable power source but do not give any information on remediation activities of the devices. Always for energy purpose, the first results from experimental paddy-field in the university farm of Yamagata University suggested that the paddy-field MFC system was a solar cell in which the plant photosynthesis was coupled to the microbial conversion of organics to electricity. Additionally, the acetate supplementation to the anode region enhanced the electricity generation in the dark, indicating possible use as a bioremediation system [190]. Field experiments at Ilgam Lake (Seoul) confirm the BMFC efficiency in mitigating $\mathrm{CH}_{4}$ emissions from hypereutrophic sediments. A $50 \Omega$ external resistance, decreases approximately 35 -fold the $\mathrm{CH}_{4}$ emissions compared to that under open-circuit operation [108]. Deploying potentiostatically poised and unpoised electrodes in riparian zone sediment of a creek during six weeks in springtime (New York State), show the poised electrodes inhibited $\mathrm{CH}_{4}$ emissions by $\sim 45 \%$ at the site with a lesser vegetation cover and highest soil temperatures. $\mathrm{N}_{2} / \mathrm{N}_{2} \mathrm{O}$ emissions were generally low at both sites and were not impacted by poised electrodes. The authors, that did not find a direct link between electrochemical treatment and microbial community membership, have shown a correspondence between environment/function and microbial community dynamics [193]. Both aesthetic and functional "floating gardens" 
associating a BMFC and a plant-MFC, hosted in a floating frame box can be built in the way: the cathode placed externally at the bottom of the floating box, directly exposed to water and the anode is buried on clay layer covered by a thick soil layer. Rice (Oryza sativa) or other aquatic plants are seeded in the soil. Some of these floating gardens have been operating for over a year [169].

\section{Technological Barriers to Breakthrough}

In principle, the use of electrodes to stimulate the microbiological oxidation of $\mathrm{OM}$ in water bodies is extremely appealing since they can potentially serve as permanent, low-cost and low maintenance electron acceptor. But BMFCs need significant improvements to become effective and controlled environmental remediation systems, widely accepted. The achievement of efficient, reliable and robust in-field electro-bioremediation, demands a setup tailored to the specific conditions of each site. And finally, resistance of operational bioremediation devices to the harsh outside conditions must be early integrated, at design stage, taking into account the specific conditions at the installation site.

Potential management needs more studies and optimisation efforts the in order to finer control bioremediation processes. Sadly almost all the articles dealing with the electrical management optimization of the MFCs concern the energy production. The resistance of the external circuit in an MFC directly influences the anode potential and the resultant bioavailability of the anode for anode respiring bacteria, giving the proper parameter to influence anode biofilm development and performance [194]. Electrochemically controlled bioremediation requires a fine tuning of the anode potential to adjust the ohmic loss variation by mean of variable resistor or a potentiostat, and this demands the use of 3-electrode setup, the only one assuring precise and well-controlled electrochemical conditions. Some progresses are needed to provide more robust and reliable field equipment over time. We have seen that many studies aim at extracting microbial electricity from sediment to supply electrical field measuring devices (sensor and data transmitter), these technological advances make it possible in the future to design bioremediation devices which are totally autonomous in energy. But progress is still needed to increase the efficiency of electron extraction, presumably by more precise management of electron flux, and reduce the energy consumption of the electronic control devices.

The ecological impacts of electro-bioremediation in real-world should be stressed and taken into account in the overall system engineering. Indeed, environmental conditions are known to deeply affect microbial communities in constructed wetlands, and therefore carbon, nitrogen and sulphur cycles [195], and they are known to remove pathogens [196]. Electro-bioremediation aims at acting on microbial communities by favouring some functions to the detriment of other functions considered undesirable. Experimental results show a microbial community structure clearly changes according to external resistance [197] with an increase in the abundance of Chloroflexi, Firmicutes and anode respiring 
bacteria like Clostridium most closely related to Desulfobulbus/Desulfocapsa genera [102], Pseudomonas sp. [163], Pseudomonas putida [151] and Geobacter sp. [183]. Furthermore different communities are capable of producing the same power level, demonstrating the flexibility and resilience of MFC systems [197]. But the fate of pathogens in an MFC-based system remains unknown. Some studies show that MFCs are endowed with a high disinfecting potential towards Escherichia coli [198] Salmonella enterica [199]. BMFC implementing in real-world requires extensive studies rarely addressed on sanitary and biodiversity hazards and biodiversity loss related to the manipulation of natural microbial populations.

Finally, to foster a widespread acceptance and practical setups of this new technology, we have to paid equal attention its potential risks on the sur-rounding ecological system and society. If subjects such as the fight against GHGs or the use of clean energies are widely accepted socially, others are touchier. Indeed, as is the case for some other new technologies, such as genetic modifications, different socio-psychological factors could potentially influence societal acceptance of in situ electro-bioremediation due to use of some "touchy issues" such as nanoparticles or toxic elements on electrodes. We must further consider how citizens make trade-offs between perceived risk and benefit, in particular in controversial application areas such as the nanotech and the so called nature invasive technologies.

More broadly to reduce maintenance costs, involvement and empowerment of local residents require a knowledge transfer in order to favor the appropriation of installed devices and ensure their sustainability over time. The new electro bioremediation solutions specifically in urban or peri-urban locations must be co-designed/developed and co-implemented in multi-stakeholder and participatory context. It is the only guarantee of the success of sustainable operation over time.

\section{Conclusions}

Electro-chemically enhanced self-purification is a new frontier needing an interdisciplinary research. It is regarded as a new sustainable and effective strategy for treatment of polluted environments, because it eliminates the injection of expensive chemicals and reduces operational energetic cost as compared to other technologies. From merging of concepts of bioremediation, electron extraction and SMFC, the idea emerges to fine tune electrochemically biodegradation processes to guide them to specific benign products. The possibility of a totally passive system, self-powered by the excess electron flux provided by microbial activity is particularly attractive. The envisioned device will impose a potential difference favouring denitrifying consortia, and banning to methanogens and sulphate-reducing bacteria, producing $\mathrm{CH}_{4}$ and $\mathrm{H}_{2} \mathrm{~S}$ respectively. In this concept we do not inject any electrons, but we fine-tune the anode potential in order to just accept the right amount of electron needed to keep a selected microbial activity, 
we passively pumps the electrons from anode respiring bacteria, and thus, drive microbial respiratory metabolism. Snorkel technique potentially represents a ground-breaking alternative to more expensive remediation options, further research efforts are needed to clarify factors and conditions affecting the snorkel-driven biodegradation processes and to identify suitable configurations for field applications. Promising results have been obtained using electro-bioremediation technologies at pilot scales, showing that these technologies may be implemented in the near future at field scales. But the two major foreseeable obstacles to the scaling-up, from the pilot scale to in-field implementation, to overcome are:

1) Maximizing the contact between anode respiring bacteria and the anode, and thus enhance the mediated oxidation processes. This will require a working on the anode geometry and its structure but also on its in-site implementation;

2) Simplify and ruggedize the system of regulation of the potential, in order to have an actual field-system, energetically autonomous and low maintenance cost.

The design and operational conditions must also be optimized to reduce the device internal resistance and improve electrochemical processes. Finally the design and engineering on the site receiving the bioremediation device are yet to be imagined, and will obviously have to be tailored to the specificities of each implementation site (e.g. geomorphology, climate, flow regime, pollutant loads). In the future, more attention should be pay to electro-bioremediation technology scaling up and in particular investigate their economic feasibility and field problems arising from the scale-up.

\section{Acknowledgements}

The authors thank the French National Research Agency (ANR 14-OHRI-0016 El Hamico), the Field Observatory in Urban Water Management (OTHUhttp://www.othu.org/, FED4161), the Rhône-Alpes Region ARC 3 Environment, ENVIMED 2015 El Encobio and Campus France (PHC Utique Carthago 17G1006 and Imhotep Mareotis 37585QA) for their scientific and financial support.

\section{References}

[1] United Nations (2015) World Urbanization Prospects, the 2014 Revision: Highlights. Department of Economic and Social Affairs, Population Division, P.D. Department of Economic and Social Affairs, Editor, Department of Economic and Social Affairs, Population Division, New York, p. 56.

[2] EC (2016) Eighth Report on the Implementation Status and the Programmes for Implementation (as required by Article 17) of Council Directive 91/271/EEC Concerning Urban Waste Water Treatment. European Council, Brussels, p. 17.

[3] Abe, K. and Kimura, H. (1996) The Possible Role of Hydrogen Sulfide as an Endogenous Neuromodulator. Journal of Neuroscience, 16, 1066-1071.

[4] Kimura, H. (2011) Hydrogen Sulfide: Its Production, Release and Functions. Amino Acids, 41, 113-121. https://doi.org/10.1007/s00726-010-0510-x 
[5] Ren, Y.S., et al. (2011) Multiple Hemodynamic Effects of Endogenous Hydrogen Sulfide on Central Nervous System in Rats. Chinese Medical Journal, 124, 3468-3475.

[6] Marsalek, J. (2006) Overview of Urban Drainage Impacts on Aquatic Habitat. In: Hlavinek, P., et al., Eds., Integrated Urban Water Resources Management, Springer, Dordrecht, 181-190. https://doi.org/10.1007/1-4020-4685-5_19

[7] Gasperi, J., et al. (2014) Micropollutants in Urban Stormwater: Occurrence, Concentrations, and Atmospheric Contributions for a Wide Range of Contaminants in Three French Catchments. Environmental Science and Pollution Research, 21, 5267-5281. https://doi.org/10.1007/s11356-013-2396-0

[8] Mohan, S.V. and Chandrasekhar, K. (2011) Self-Induced Bio-Potential and Graphite Electron Accepting Conditions Enhances Petroleum Sludge Degradation in Bio-Electrochemical System with Simultaneous Power Generation. Bioresource Technology, 102, 9532-9541. https://doi.org/10.1016/j.biortech.2011.07.038

[9] Rodrigo, M.A., Oturan, N. and Oturan, M.A. (2014) Electrochemically Assisted Remediation of Pesticides in Soils and Water: A Review. Chemical Reviews, 114, 8720-8745. https://doi.org/10.1021/cr500077e

[10] Li, W.W. and Yu, H.Q. (2015) Stimulating Sediment Bioremediation with Benthic Microbial Fuel Cells. Biotechnology Advances, 33, 1-12.

https://doi.org/10.1016/j.biotechadv.2014.12.011

[11] Doherty, L., et al. (2015) A Review of a Recently Emerged Technology: Constructed Wetland-Microbial Fuel Cells. Water Research, 85, 38-45. https://doi.org/10.1016/j.watres.2015.08.016

[12] Daghio, M., et al. (2017) Electrobioremediation of Oil Spills. Water Research, 114, 351-370. https://doi.org/10.1016/j.watres.2017.02.030

[13] Li, X.J., et al. (2017) Microbial Fuel Cells for Organic-Contaminated Soil Remedial Applications: A Review. Energy Technology, 5, 1156-1164. https://doi.org/10.1002/ente.201600674

[14] Santoro, C., et al. (2017) Microbial Fuel Cells: From Fundamentals to Applications. A Review. Journal of Power Sources, 356, 225-244. https://doi.org/10.1016/j.jpowsour.2017.03.109

[15] Bellagamba, M., et al. (2017) Electrolysis-Driven Bioremediation of Crude OilContaminated Marine Sediments. New Biotechnology, 38, 84-90. https://doi.org/10.1016/j.nbt.2016.03.003

[16] Namour, P. (1999) Auto-épuration des rejets organiques domestiques, nature de la matière organique résiduaire et son effet en rivière, in Ecologie. Université de Lyon, Lyon. https://irsteadoc.irstea.fr/cemoa/

[17] Namour, P. and Le Pimpec, P. (2001) Simulation of Hyporheic Self-Purification in Rivers: The Assimilative Capacity of Proteins. Water Science and Technology, 43, 231-238.

[18] Bertrand, J.-C., et al. (2011) Ecologie Microbienne: Microbiologie des milieux naturels et anthropisés. Presse Universitaire de Pau ed.

[19] Borch, T., et al. (2010) How Electron Flow Controls Contaminant Dynamics. Environmental Science \& Technology, 44, 3-6. https://doi.org/10.1021/es903264z

[20] Lefebvre, S., Marmonier, P. and Pinay, G. (2004) Stream Regulation and Nitrogen Dynamics in Sediment Interstices: Comparison of Natural and Straightened Sectors of a Third-Order Stream. River Research and Applications, 20, 499-512. https://doi.org/10.1002/rra.765 
[21] Hargrave, B.T., Holmer, M. and Newcombe, C.P. (2008) Towards a Classification of Organic Enrichment in Marine Sediments Based on Biogeochemical Indicators. Marine Pollution Bulletin, 56, 810-824. https://doi.org/10.1016/j.marpolbul.2008.02.006

[22] Diaz, R.J. and Rosenberg, R. (2008) Spreading Dead Zones and Consequences for Marine Ecosystems. Science, 321, 926-929. https://doi.org/10.1126/science.1156401

[23] Namour, P., et al. (2015) Stream Pollution Concentration in Riffle Geomorphic Units (Yzeron Basin, France). Sciences of the Total Environment, 532, 80-90. https://doi.org/10.1016/j.scitotenv.2015.05.057

[24] Aufdenkampe, A.K., et al. (2011) Riverine Coupling of Biogeochemical Cycles between Land, Oceans, and Atmosphere. Frontiers in Ecology and the Environment, 9, 53-60. https://doi.org/10.1890/100014

[25] Birgand, F., et al. (2007) Nitrogen Removal in Streams of Agricultural CatchmentsA Literature Review. Critical Reviews in Environmental Science \& Technology, 37, 381-487. https://doi.org/10.1080/10643380600966426

[26] Bohlke, J.K., Harvey, J.W. and Voytek, M.A. (2004) Reach-Scale Isotope Tracer Experiment to Quantify Denitrification and Related Processes in a Nitrate-Rich Stream, Midcontinent United States. Limnology and Oceanography, 49, 821-838. https://doi.org/10.4319/lo.2004.49.3.0821

[27] Jones, J.B. and Mulholland, P.J. (1998) Methane Input and Evasion in a Hardwood Forest Stream: Effects of Subsurface Flow from Shallow and Deep Pathways. Limnology and Oceanography, 43, 1243-1250. https://doi.org/10.4319/lo.1998.43.6.1243

[28] Hope, D., et al. (2001) Carbon Dioxide and Methane Evasion from a Temperate Peatland Stream. Limnology and Oceanography, 46, 847-857. https://doi.org/10.4319/lo.2001.46.4.0847

[29] Hlaváčová, E., et al. (2006) Greenhouse Gas $\left(\mathrm{CO}_{2}, \mathrm{CH}_{4}, \mathrm{~N}_{2} \mathrm{O}\right)$ Emissions to the Atmosphere from a Small Lowland Stream in Czech Republic. Archiv fur Hydrobiologie, 165, 339-353. https://doi.org/10.1127/0003-9136/2006/0165-0339

[30] Van Amstel, A. (2012) Methane. A Review. Journal of Integrative Environmental Sciences, 9, 5-30. https://doi.org/10.1080/1943815X.2012.694892

[31] Nisbet, E.G., Dlugokencky, E.J. and Bousquet, P. (2014) Methane on the Rise-Again. Science, 343, 493-495. https://doi.org/10.1126/science.1247828

[32] Eijo-Río, E., et al. (2015) Municipal Sewer Networks as Sources of Nitrous Oxide, Methane and Hydrogen Sulphide Emissions: A Review and Case Studies of Atlantic and Mediterranean-Climate Spanish Cities. Journal of Environmental Chemical Engineering, 3, 2084-2094. https://doi.org/10.1016/j.jece.2015.07.006

[33] Stanley, E.H., et al. (2016) The Ecology of Methane in Streams and Rivers: Patterns, Controls, and Global Significance. Ecological Monographs, 86, 146-171. https://doi.org/10.1890/15-1027

[34] Harrison, J.A., Matson, P.A. and Fendorf, S.E. (2005) Effects of a Diel Oxygen Cycle on Nitrogen Transformations and Greenhouse Gas Emissions in a Eutrophied Subtropical Stream. Aquatic Sciences, 67, 308-315. https://doi.org/10.1007/s00027-005-0776-3

[35] Clough, T.J., et al. (2007) Diurnal Fluctuations of Dissolved Nitrous Oxide $\left(\mathrm{N}_{2} \mathrm{O}\right)$ Concentrations and Estimates of $\mathrm{N}_{2} \mathrm{O}$ Emissions from a Spring-Fed River: Implications for IPCC Methodology. Global Change Biology, 13, 1016-1027. https://doi.org/10.1111/j.1365-2486.2007.01337.x 
[36] Silvennoinen, H., et al. (2008) Greenhouse Gas Fluxes from the Eutrophic Temmesjoki River and Its Estuary in the Liminganlahti Bay (the Baltic Sea). Biogeochemis try, 90, 193-208. https://doi.org/10.1007/s10533-008-9244-1

[37] Beaulieu, J.J., et al. (2008) The Production and Emission of Nitrous Oxide from Headwater Streams in the Midwestern United States. Global Change Biology, 14, 878-894. https://doi.org/10.1111/j.1365-2486.2007.01485.x

[38] IPCC (2013) Climate Change 2013: The Physical Science Basis. In: Stocker, T.F., et al., Eds., Contribution of Working Group I to the 5 th Assessment Report of the Intergovernmental Panel on Climate Change, IPCC, Cambridge (UK) \& New York, p. 1525.

[39] Saunois, M., et al. (2016) The Global Methane Budget 2000-2012. Earth System Science Data, 8, 697-751. https://doi.org/10.5194/essd-8-697-2016

[40] Bastviken, D., et al. (2011) Freshwater Methane Emissions Offset the Continental Carbon Sink. Science, 331, 50. https://doi.org/10.1126/science.1196808

[41] Evans, C.D., Renou-Wilson, F. and Strack, M. (2016) The Role of Waterborne Carbon in the Greenhouse Gas Balance of Drained and Re-Wetted Peatlands. Aquatic Sciences, 78, 573-590. https://doi.org/10.1007/s00027-015-0447-y

[42] Singh, S.N., Kulshreshtha, K. and Agnihotri, S. (2000) Seasonal Dynamics of Methane Emission from Wetlands. Chemosphere-Global Change Science, 2, 39-46. https://doi.org/10.1016/S1465-9972(99)00046-X

[43] Li, D.M., et al. (2011) Methane Emissions from Double-Rice Cropping System under Conventional and No Tillage in Southeast China. Soil \& Tillage Research, 113, 77-81. https://doi.org/10.1016/j.still.2011.02.006

[44] Beaulieu, J.J., Shuster, W.D. and Rebholz, J.A. (2010) Nitrous Oxide Emissions from a Large, Impounded River: The Ohio River. Environmental Science \& Technology, 44, 7527-7533. https://doi.org/10.1021/es1016735

[45] Hinshaw, S.E. and Dahlgren, R.A. (2012) Dissolved Nitrous Oxide Concentrations and Fluxes from the Eutrophic San Joaquin River, California. Environmental Science \& Technology, 47, 1313-1322. https://doi.org/10.1021/es301373h

[46] Wilcock, R.J. and Sorrell, B.K. (2008) Emissions of Greenhouse Gases $\mathrm{CH}_{4}$ and $\mathrm{N}_{2} \mathrm{O}$ from Low-Gradient Streams in Agriculturally Developed Catchments. Water, Air, and Soil Pollution, 188, 155-170. https://doi.org/10.1007/s11270-007-9532-8

[47] Sobek, S., et al. (2012) Extreme Organic Carbon Burial Fuels Intense Methane Bubbling in a Temperate Reservoir. Geophysical Research Letters, 39. https://doi.org/10.1029/2011GL050144

[48] Maeck, A., et al. (2013) Sediment Trapping by Dams Creates Methane Emission Hot Spots. Environmental Science \& Technology, 47, 8130-8137. https://doi.org/10.1021/es4003907

[49] Hinshaw, S.E. and Dahlgren, R.A. (2013) Dissolved Nitrous Oxide Concentrations and Fluxes from the Eutrophic San Joaquin River, California. Environmental Science \& Technology, 47, 1313-1322. https://doi.org/10.1021/es301373h

[50] Seitzinger, S.P., Kroeze, C. and Styles, R.V. (2000) Global Distribution of $\mathrm{N}_{2} \mathrm{O}$ Emissions from Aquatic Systems: Natural Emissions and Anthropogenic Effects. Chemosphere-Global Change Science, 2, 267-279. https://doi.org/10.1016/S1465-9972(00)00015-5

[51] van Niftrik, L. and Jetten, M.S.M. (2012) Anaerobic Ammonium-Oxidizing Bacteria: Unique Microorganisms with Exceptional Properties. Microbiology and Molecular Biology Reviews, 76, 585-596. https://doi.org/10.1128/MMBR.05025-11 
[52] Brandes, J.A., Devol, A.H. and Deutsch, C. (2007) New Developments in the Marine Nitrogen Cycle. Chemical Reviews, 107, 577-589. https://doi.org/10.1021/cr050377t

[53] Gao, H., et al. (2010) Aerobic Denitrification in Permeable Wadden Sea Sediments. ISME Journal, 4, 417-426. https://doi.org/10.1038/ismej.2009.127

[54] Reeburgh, W. (2003) Global Methane Biogeochemistry. In: Keeling, R., Holland, H. and Turekian, K., Eds., Treatise on Geochemistry, Elsevier-Pergamon, Oxford, UK, 65-89.

[55] Friedrich, M.W. (2005) Methyl-Coenzyme M Reductase Genes: Unique Functional Markers for Methanogenic and Anaerobic Methane-Oxidizing Archaea. In: Leadbetter, J.R., Ed., Environmental Microbiology, Elsevier Academic Press Inc., San Diego, 428-442. https://doi.org/10.1016/S0076-6879(05)97026-2

[56] Penning, H., et al. (2006) Carbon Isotope Fractionation during Acetoclastic Methanogenesis by Methanosaeta concilii in Culture and a Lake Sediment. Applied and Environmental Microbiology, 72, 5648-5652. https://doi.org/10.1128/AEM.00727-06

[57] Penning, H., et al. (2005) Variation of Carbon Isotope Fractionation in Hydrogenotrophic Methanogenic Microbial Cultures and Environmental Samples at Different Energy Status. Global Change Biology, 11, 2103-2113. https://doi.org/10.1111/j.1365-2486.2005.01076.x

[58] Lyautey, E., et al. (2013) Abundance, Activity and Structure of Denitrifier Communities in Phototrophic River Biofilms (River Garonne, France). Hydrobiologia, 716, 177-187. https://doi.org/10.1007/s10750-013-1561-2

[59] Dubey, S.K., et al. (2013) Changes in Methanogenic Population Size and $\mathrm{CH}_{4}$ Production Potential in Response to Crop Phenology in Tropical Rice Field. Soil Biology \& Biochemistry, 57, 972-978. https://doi.org/10.1016/j.soilbio.2012.07.001

[60] EPA (2013) Introduction to In Situ Bioremediation of Groundwater. U.S. Environmental Protection Agency Office of Superfund Remediation and Technology Innovation, p. 89.

[61] Lofrano, G., et al. (2017) In Situ Remediation of Contaminated Marine Sediment: An Overview. Environmental Science and Pollution Research, 24, 5189-5206. https://doi.org/10.1007/s11356-016-8281-x

[62] Kasahara, T., et al. (2006) Effects of Riffle-Step Restoration on Hyporheic Zone Chemistry in N-Rich Lowland Streams. Canadian Journal of Fisheries and Aquatic Sciences, 63, 120-133. https://doi.org/10.1139/f05-199

[63] Mendoza-Lera, C. and Datry, T. (2017) Relating Hydraulic Conductivity and Hyporheic Zone Biogeochemical Processing to Conserve and Restore River Ecosystem Services. Science of the Total Environment, 579, 1815-1821. https://doi.org/10.1016/j.scitotenv.2016.11.166

[64] Vymazal, J. (2009) The Use Constructed Wetlands with Horizontal Sub-Surface Flow for Various Types of Wastewater. Ecological Engineering, 35, 1-17. https://doi.org/10.1016/j.ecoleng.2008.08.016

[65] Guimarães, B.C.M., et al. (2010) Microbial Services and Their Management: Recent Progresses in Soil Bioremediation Technology. Applied Soil Ecology, 46, 157-167. https://doi.org/10.1016/j.apsoil.2010.06.018

[66] Gillespie, I.M.M. and Philp, J.C. (2013) Bioremediation, an Environmental Remediation Technology for the Bioeconomy. Trends in Biotechnology, 31, 329-332. https://doi.org/10.1016/j.tibtech.2013.01.015 
[67] Aulenta, F., et al. (2009) Microbial Reductive Dechlorination of Trichloroethene to Ethene with Electrodes Serving as Electron Donors without the External Addition of Redox Mediators. Biotechnology and Bioengineering, 103, 85-91. https://doi.org/10.1002/bit.22234

[68] Virdis, B., et al. (2010) Simultaneous Nitrification, Denitrification and Carbon Removal in Microbial Fuel Cells. Water Research, 44, 2970-2980. https://doi.org/10.1016/j.watres.2010.02.022

[69] Huang, L.P., Cheng, S.A. and Chen, G.H. (2011) Bioelectrochemical Systems for Efficient Recalcitrant Wastes Treatment. Journal of Chemical Technology and Biotechnology, 86, 481-491. https://doi.org/10.1002/jctb.2551

[70] Lovley, D.R. (2012) Electromicrobiology. In: Gottesman, S., Harwood, C.S. and Schneewind, O., Eds., Annual Review of Microbiology, Vol. 66, Annual Reviews, Palo Alto, 391-409. https://doi.org/10.1146/annurev-micro-092611-150104

[71] Malvankar, N.S. and Lovley, D.R. (2014) Microbial Nanowires for Bioenergy Applications. Current Opinion in Biotechnology, 27, 88-95. https://doi.org/10.1016/j.copbio.2013.12.003

[72] Lovley, D.R., et al. (1996) Humic Substances as Electron Acceptors for Microbial Respiration. Nature, 382, 445-448. https://doi.org/10.1038/382445a0

[73] Chang, I.S., et al. (2004) Continuous Determination of Biochemical Oxygen Demand Using Microbial Fuel Cell Type Biosensor. Biosensors \& Bioelectronics, 19, 607-613. https://doi.org/10.1016/S0956-5663(03)00272-0

[74] Moon, H., et al. (2004) Improving the Dynamic Response of a Mediator-Less Microbial Fuel Cell as a Biochemical Oxygen Demand (BOD) Sensor. Biotechnology Letters, 26, 1717-1721. https://doi.org/10.1007/s10529-004-3743-5

[75] Park, H.S., et al. (2001) A Novel Electrochemically Active and Fe(III)-Reducing Bacterium Phylogenetically Related to Clostridium butyricum Isolated from a Microbial Fuel Cell. Anaerobe, 7, 297-306. https://doi.org/10.1006/anae.2001.0399

[76] Kim, M.N. and Park, K.H. (2001) Klebsiella BOD Sensor. Sensors \& Actuators, B: Chemical, 80, 9-14. https://doi.org/10.1016/S0925-4005(01)00879-6

[77] Yan, Z.S., et al. (2017) Interconnection of Key Microbial Functional Genes for Enhanced Benzo a pyrene Biodegradation in Sediments by Microbial Electrochemistry. Environmental Science \& Technology, 51, 8519-8529. https://doi.org/10.1021/acs.est.7b00209

[78] Reguera, G., et al. (2005) Extracellular Electron Transfer via Microbial Nanowires. Nature, 435, 1098-1101. https://doi.org/10.1038/nature03661

[79] Rabaey, K., et al. (2004) Biofuel Cells Select for Microbial Consortia That Self-Mediate Electron Transfer. Applied and Environmental Microbiology, 70, 5373-5382. https://doi.org/10.1128/AEM.70.9.5373-5382.2004

[80] Arends, J.B.A. and Verstraete, W. (2012) 100 Years of Microbial Electricity Production: Three Concepts for the Future. Microbial Biotechnology, 5, 333-346. https://doi.org/10.1111/j.1751-7915.2011.00302.x

[81] Logan, B.E., et al. (2006) Microbial Fuel Cells: Methodology and Technology. Environmental Science \& Technology, 40, 5181-5192. https://doi.org/10.1021/es0605016

[82] Reimers, C.E., et al. (2001) Harvesting Energy from the Marine Sediment-Water Interface. Environmental Science \& Technology, 35, 192-195. https://doi.org/10.1021/es001223s

[83] Reimers, C.E., et al. (2006) Microbial Fuel Cell Energy from an Ocean Cold Seep. Geobiology, 4, 123-136. https://doi.org/10.1111/j.1472-4669.2006.00071.x 
[84] Dumas, C., et al. (2007) Marine Microbial Fuel Cell: Use of Stainless Steel Electrodes as Anode and Cathode Materials. Electrochimica Acta, 53, 468-473. https://doi.org/10.1016/j.electacta.2007.06.069

[85] Girguis, P.R., Nielsen, M.E. and Figueroa, I. (2010) Harnessing Energy from Marine Productivity Using Bioelectrochemical Systems. Current Opinion in Biotechnology, 21, 252-258. https://doi.org/10.1016/j.copbio.2010.03.015

[86] Donovan, C., et al. (2008) Batteryless, Wireless Sensor Powered by a Sediment Microbial Fuel Cell. Environmental Science \& Technology, 42, 8591-8596. https://doi.org/10.1021/es801763g

[87] Venkata Mohan, S., et al. (2009) Evaluation of the Potential of Various Aquatic Eco-Systems in Harnessing Bioelectricity through Benthic Fuel Cell: Effect of Electrode Assembly and Water Characteristics. Bioresource Technology, 100, 2240-2246. https://doi.org/10.1016/j.biortech.2008.10.020

[88] Song, T.S., et al. (2012) Effect of Graphite Felt and Activated Carbon Fiber Felt on Performance of Freshwater Sediment Microbial Fuel Cell. Journal of Chemical Technology and Biotechnology, 87, 1436-1440. https://doi.org/10.1002/jctb.3764

[89] Namour, P., et al. (2014) Energy Harvesting from River Sediment Using a Microbial Fuel Cell: Preliminary Results. Sensors \& Transducers Journal, 27, 290-294.

[90] Wang, H. and Ren, Z.J. (2013) A Comprehensive Review of Microbial Electrochemical Systems as a Platform Technology. Biotechnology Advances, 31, 1796-1807. https://doi.org/10.1016/j.biotechadv.2013.10.001

[91] Reddy, K.R. and Cameselle, C. (2009) Electrochemical Remediation Technologies for Polluted Soils, Sediments and Groundwater. John Wiley \& Sons, 732. https://doi.org/10.1002/9780470523650

[92] Rosenbaum, M.A. and Franks, A.E. (2014) Microbial Catalysis in Bioelectrochemical Technologies: Status Quo, Challenges and Perspectives. Applied Microbiology and Biotechnology, 98, 509-518. https://doi.org/10.1007/s00253-013-5396-6

[93] Kelly, P.T. and He, Z. (2014) Nutrients Removal and Recovery in Bioelectrochemical Systems: A Review. Bioresource Technology, 153, 351-360.

https://doi.org/10.1016/j.biortech.2013.12.046

[94] Wang, H.M. and Ren, Z.Y.J. (2013) A Comprehensive Review of Microbial Electrochemical Systems as a Platform Technology. Biotechnology Advances, 31, 1796-1807. https://doi.org/10.1016/j.biotechadv.2013.10.001

[95] Virdis, B., et al. (2011) Microbial Fuel Cells. In: Wilderer, P., Ed., Treatise on Water Science, Elsevier, Oxford (UK), 641-665. https://doi.org/10.1016/B978-0-444-53199-5.00098-1

[96] Liu, W.K., Brown, M.R.W. and Elliott, T.S.J. (1997) Mechanisms of the Bactericidal Activity of Low Amperage Electric Current (DC). Journal of Antimicrobial Chemotherapy, 39, 687-695. https://doi.org/10.1093/jac/39.6.687

[97] Aelterman, P., et al. (2008) The Anode Potential Regulates Bacterial Activity in Microbial Fuel Cells. Applied Microbiology and Biotechnology, 78, 409-418. https://doi.org/10.1007/s00253-007-1327-8

[98] Yan, Z.S., et al. (2012) Enhanced Degradation of Phenanthrene and Pyrene in Freshwater Sediments by Combined Employment of Sediment Microbial Fuel Cell and Amorphous Ferric Hydroxide. Journal of Hazardous Materials, 199, 217-225. https://doi.org/10.1016/j.jhazmat.2011.10.087

[99] Zhang, T., et al. (2010) Stimulating the Anaerobic Degradation of Aromatic Hydrocarbons in Contaminated Sediments by Providing an Electrode as the Electron Acceptor: Anaerobic Biodegradation of Aromatics with Electrode. Environmental Microbiology, 12, 1011-1020. https://doi.org/10.1111/j.1462-2920.2009.02145.x 
[100] Torres, C.I., et al. (2009) Selecting Anode-Respiring Bacteria Based on Anode Potential: Phylogenetic, Electrochemical, and Microscopic Characterization. Environmental Science \& Technology, 43, 9519-9524. https://doi.org/10.1021/es902165y

[101] Jung, S. and Regan, J.M. (2011) Influence of External Resistance on Electrogenesis, Methanogenesis, and Anode Prokaryotic Communities in Microbial Fuel Cells. Applied and Environmental Microbiology, 77, 564-571. https://doi.org/10.1128/AEM.01392-10

[102] Ryckelynck, N., Stecher, H.A. and Reimers, C.E. (2005) Understanding the Anodic Mechanism of a Seafloor Fuel Cell: Interactions between Geochemistry and Microbial Activity. Biogeochemistry, 76, 113-139. https://doi.org/10.1007/s10533-005-2671-3

[103] Zhang, F., Tian, L. and He, Z. (2011) Powering a Wireless Temperature Sensor Using Sediment Microbial Fuel Cells with Vertical Arrangement of Electrodes. Journal of Power Sources, 22, 9568-9573. https://doi.org/10.1016/j.jpowsour.2011.07.037

[104] Yang, Y., et al. (2015) Enhancing the Bioremediation by Harvesting Electricity from the Heavily Contaminated Sediments. Bioresource Technology, 179, 615-618. https://doi.org/10.1016/j.biortech.2014.12.034

[105] Gonzalez-Gamboa, N.K., et al. (2017) Removal of Organic Matter and Electricity Generation of Sediments from Progreso, Yucatan, Mexico, in a Sediment Microbial Fuel Cell. Environmental Science and Pollution Research, 24, 5868-5876. https://doi.org/10.1007/s11356-016-8286-5

[106] Esteve-Nunez, A., et al. (2005) Growth of Geobacter sulfurreducens under Nutrient-Limiting Conditions in Continuous Culture. Environmental Microbiology, 7, 641-648. https://doi.org/10.1111/j.1462-2920.2005.00731.x

[107] Qu, X., et al. (2009) Anaerobic Biodegradation of Cellulosic Material: Batch Experiments and Modelling Based on Isotopic Data and Focusing on Aceticlastic and Non-Aceticlastic Methanogenesis. Waste Management, 29, 1828-1837. https://doi.org/10.1016/j.wasman.2008.12.008

[108] Jeon, H.J., et al. (2012) Electrochemical Control of Methane Emission from Lake Sediment Using Microbial Fuel Cells. Bulletin of the Korean Chemical Society, 33, 2401-2404. https://doi.org/10.5012/bkcs.2012.33.7.2401

[109] Logan, B.E., et al. (2006) Microbial Fuel Cells: Methodology and Technology. Environmental Science \& Technology, 40, 5181-5192. https://doi.org/10.1021/es0605016

[110] Namour, P., et al. (2014) Energy Harvesting from River Sediment Using a Microbial Fuel Cell: Preliminary Results. Sensors \& Transducers Journal, 27, 290-294.

[111] Hou, J.X., et al. (2014) Three-Dimensional Macroporous Anodes Based on Stainless Steel Fiber Felt for High-Performance Microbial Fuel Cells. Journal of Power Sources, 258, 204-209. https://doi.org/10.1016/j.jpowsour.2014.02.035

[112] Ketep, S.F., et al. (2014) Stainless Steel Foam Increases the Current Produced by Microbial Bioanodes in Bioelectrochemical Systems. Energy \& Environmental Science, 7, 1633-1637. https://doi.org/10.1039/C3EE44114H

[113] Guo, K., et al. (2014) Flame Oxidation of Stainless Steel Felt Enhances Anodic Biofilm Formation and Current Output in Bioelectrochemical Systems. Environmental Science \& Technology, 48, 7151-7156. https://doi.org/10.1021/es500720g

[114] Rosenbaum, M., et al. (2006) Interfacing Electrocatalysis and Biocatalysis with Tungsten Carbide: A High-Performance, Noble-Metal-Free Microbial Fuel Cell. Angewandte Chemie-International Edition, 45, 6658-6661.

https://doi.org/10.1002/anie.200602021 
[115] ter Heijne, A., et al. (2008) Performance of Non-Porous Graphite and TitaniumBased Anodes in Microbial Fuel Cells. Electrochimica Acta, 53, 5697-5703. https://doi.org/10.1016/j.electacta.2008.03.032

[116] Richter, H., et al. (2008) Electricity Generation by Geobacter sulfurreducens Attached to Gold Electrodes. Langmuir, 24, 4376-4379. https://doi.org/10.1021/la703469y

[117] Guo, K., et al. (2015) Engineering Electrodes for Microbial Electrocatalysis. Current Opinion in Biotechnology, 33, 149-156. https://doi.org/10.1016/j.copbio.2015.02.014

[118] Zhou, M., et al. (2011) An Overview of Electrode Materials in Microbial Fuel Cells. Journal of Power Sources, 196, 4427-4435. https://doi.org/10.1016/j.jpowsour.2011.01.012

[119] Wei, J.C., Liang, P. and Huang, X. (2011) Recent Progress in Electrodes for Microbial Fuel Cells. Bioresource Technology, 102, 9335-9344. https://doi.org/10.1016/j.biortech.2011.07.019

[120] Arends, J.B.A., et al. (2012) Suitability of Granular Carbon as an Anode Material for Sediment Microbial Fuel Cells. Journal of Soils and Sediments, 12, 1197-1206. https://doi.org/10.1007/s11368-012-0537-6

[121] Chen, S.L., et al. (2012) Layered Corrugated Electrode Macrostructures Boost Microbial Bioelectrocatalysis. Energy \& Environmental Science, 5, 9769-9772. https://doi.org/10.1039/c2ee23344d

[122] Namour, P., et al. (2014) Energy Harvesting from River Sediment Using a Microbial Fuel Cell: Preliminary Results. Sensors \& Transducers, 27, 290-294.

[123] Karra, U., et al. (2014) Performance Evaluation of Activated Carbon-Based Electrodes with Novel Power Management System for Long-Term Benthic Microbial Fuel Cells. International Journal of Hydrogen Energy, 39, 21847-21856. https://doi.org/10.1016/j.ijhydene.2014.06.095

[124] Le, T.X.H., Bechelany, M. and Cretin, M. (2017) Carbon Felt Based-Electrodes for Energy and Environmental Applications: A Review. Carbon, 122, 564-591. https://doi.org/10.1016/j.carbon.2017.06.078

[125] Mohanakrishna, G., Mohan, S.K. and Mohan, S.V. (2012) Carbon Based Nanotubes and Nanopowder as Impregnated Electrode Structures for Enhanced Power Generation: Evaluation with Real Field Wastewater. Applied Energy, 95, 31-37. https://doi.org/10.1016/j.apenergy.2012.01.058

[126] Erbay, C., et al. (2015) Three-Dimensional Porous Carbon Nanotube Sponges for High-Performance Anodes of Microbial Fuel Cells. Journal of Power Sources, 298, 177-183. https://doi.org/10.1016/j.jpowsour.2015.08.021

[127] Logan, B., et al. (2007) Graphite Fiber Brush Anodes for Increased Power Production in Air-Cathode Microbial Fuel Cells. Environmental Science \& Technology, 41, 3341-3346. https://doi.org/10.1021/es062644y

[128] Ahn, Y. and Logan, B.E. (2010) Effectiveness of Domestic Wastewater Treatment Using Microbial Fuel Cells at Ambient and Mesophilic Temperatures. Bioresource Technology, 101, 469-475. https://doi.org/10.1016/j.biortech.2009.07.039

[129] Santoro, C., et al. (2015) Influence of Anode Surface Chemistry on Microbial Fuel Cell Operation. Bioelectrochemistry, 106, 141-149. https://doi.org/10.1016/j.bioelechem.2015.05.002

[130] Picot, M., et al. (2011) Graphite Anode Surface Modification with Controlled Reduction of Specific Aryl Diazonium Salts for Improved Microbial Fuel Cells Power Output. Biosensors \& Bioelectronics, 28, 181-188. https://doi.org/10.1016/j.bios.2011.07.017 
[131] Wang, X., et al. (2009) Use of Carbon Mesh Anodes and the Effect of Different Pretreatment Methods on Power Production in Microbial Fuel Cells. Environmental Science \& Technology, 43, 6870-6874. https://doi.org/10.1021/es900997w

[132] Feng, Y.J., et al. (2010) Treatment of Carbon Fiber Brush Anodes for Improving Power Generation in Air-Cathode Microbial Fuel Cells. Journal of Power Sources, 195, 1841-1844. https://doi.org/10.1016/j.jpowsour.2009.10.030

[133] Cheng, S.A. and Logan, B.E. (2007) Ammonia Treatment of Carbon Cloth Anodes to Enhance Power Generation of Microbial Fuel Cells. Electrochemistry Communications, 9, 492-496. https://doi.org/10.1016/j.elecom.2006.10.023

[134] Saito, T., et al. (2011) Effect of Nitrogen Addition on the Performance of Microbial Fuel Cell Anodes. Bioresource Technology, 102, 395-398.

https://doi.org/10.1016/j.biortech.2010.05.063

[135] Safari, M., et al. (2014) Bio-Electrochemical Reduction of Nitrate Utilizing MWCNT Supported on Carbon Base Electrodes: A Comparison Study. Journal of the Taiwan Institute of Chemical Engineers, 45, 2212-2216. https://doi.org/10.1016/j.jtice.2014.05.006

[136] Scott, K., et al. (2008) Fuel Cell Power Generation from Marine Sediments: Investigation of Cathode Materials. Journal of Chemical Technology and Biotechnology, 83, 1244-1254. https://doi.org/10.1002/jctb.1937

[137] Lyautey, E., et al. (2011) Electroactivity of Phototrophic River Biofilms and Constitutive Cultivable Bacteria. Applied and Environmental Microbiology, 77, 5394-5401. https://doi.org/10.1128/AEM.00500-11

[138] Najafgholi, Z. and Rahimnejad, M. (2016) Improvement of Sediment Microbial Fuel Cell Performance by Application of Sun Light and Biocathode. Korean Journal of Chemical Engineering, 33, 154-158. https://doi.org/10.1007/s11814-015-0123-X

[139] Lowy, D.A., et al. (2006) Harvesting Energy from the Marine Sediment-Water Interface II-Kinetic Activity of Anode Materials. Biosensors \& Bioelectronics, 21, 2058-2063. https://doi.org/10.1016/j.bios.2006.01.033

[140] Zhang, L.X., et al. (2009) Manganese Dioxide as an Alternative Cathodic Catalyst to Platinum in Microbial Fuel Cells. Biosensors \& Bioelectronics, 24, 2825-2829. https://doi.org/10.1016/j.bios.2009.02.010

[141] Clauwaert, P., et al. (2007) Open Air Biocathode Enables Effective Electricity Generation with Microbial Fuel Cells. Environmental Science \& Technology, 41, 7564-7569. https://doi.org/10.1021/es0709831

[142] Guo, K., et al. (2013) Spontaneous Modification of Carbon Surface with Neutral Red from Its Diazonium Salts for Bioelectrochemical Systems. Biosensors \& Bioelectronics, 47, 184-189. https://doi.org/10.1016/j.bios.2013.02.051

[143] Rezaee, A., Safari, M. and Hossini, H. (2015) Bioelectrochemical Denitrification Using Carbon Felt/Multiwall Carbon Nanotube. Environmental Technology, 36, 1057-1062. https://doi.org/10.1080/09593330.2014.974680

[144] An, J., et al. (2013) Comparison in Performance of Sediment Microbial Fuel Cells According to Depth of Embedded Anode. Bioresource Technology, 127, 138-142. https://doi.org/10.1016/j.biortech.2012.09.095

[145] Oon, Y.L., et al. (2016) Synergistic Effect of Up-Flow Constructed Wetland and Microbial Fuel Cell for Simultaneous Wastewater Treatment and Energy Recovery. Bioresource Technology, 203, 190-197.

https://doi.org/10.1016/j.biortech.2015.12.011

[146] Song, H.L., et al. (2017) Optimization of Bioelectricity Generation in Constructed Wetland-Coupled Microbial Fuel Cell Systems. Water, 9, 185.

https://doi.org/10.3390/w9030185 
[147] Yu, B., Tian, J. and Feng, L. (2017) Remediation of PAH Polluted Soils Using a Soil Microbial Fuel Cell: Influence of Electrode Interval and Role of Microbial Community. Journal of Hazardous Materials, 336, 110-118. https://doi.org/10.1016/j.jhazmat.2017.04.066

[148] Williams, K.H., et al. (2010) Electrode-Based Approach for Monitoring In Situ Microbial Activity during Subsurface Bioremediation. Environmental Science \& Technology, 44, 47-54. https://doi.org/10.1021/es9017464

[149] Yuan, Y., Zhou, S.G. and Zhuang, L. (2010) A New Approach to in Situ Sediment Remediation Based on Air-Cathode Microbial Fuel Cells. Journal of Soils and Sediments, 10, 1427-1433. https://doi.org/10.1007/s11368-010-0276-5

[150] Lu, L., et al. (2014) Enhanced Bioremediation of Hydrocarbon-Contaminated Soil Using Pilot-Scale Bioelectrochemical Systems. Journal of Hazardous Materials, 274, 8-15. https://doi.org/10.1016/j.jhazmat.2014.03.060

[151] Lu, L., et al. (2014) Microbial Metabolism and Community Structure in Response to Bioelectrochemically Enhanced Remediation of Petroleum Hydrocarbon-Contaminated Soil. Environmental Science \& Technology, 48, 4021-4029. https://doi.org/10.1021/es4057906

[152] Morris, J.M. and Jin, S. (2012) Enhanced Biodegradation of HydrocarbonContaminated Sediments Using Microbial Fuel Cells. Journal of Hazardous Materials, 213, 474-477. https://doi.org/10.1016/j.jhazmat.2012.02.029

[153] He, Z., et al. (2006) An Upflow Microbial Fuel Cell with an Interior Cathode: Assessment of the Internal Resistance by Impedance Spectroscopy. Environmental Science \& Technology, 40, 5212-5217. https://doi.org/10.1021/es060394f

[154] Wang, X., et al. (2012) Bioelectrochemical Stimulation of Petroleum Hydrocarbon Degradation in Saline Soil Using U-Tube Microbial Fuel Cells. Biotechnology and Bioengineering, 109, 426-433. https://doi.org/10.1002/bit.23351

[155] Erable, B., Etcheverry, L. and Bergel, A. (2011) From Microbial Fuel Cell (MFC) to Microbial Electrochemical Snorkel (MES): Maximizing Chemical Oxygen Demand (COD) Removal from Wastewater. Biofouling, 27, 319-326. https://doi.org/10.1080/08927014.2011.564615

[156] Viggi, C.C., et al. (2015) The "Oil-Spill Snorkel”: An Innovative Bioelectrochemical Approach to Accelerate Hydrocarbons Biodegradation in Marine Sediments. Frontiers in Microbiology, 6, No. 881, 1-11. https://doi.org/10.3389/fmicb.2015.00881

[157] Hsu, L., et al. (2013) Scale up Considerations for Sediment Microbial Fuel Cells. RSC Advances, 3, 15947. https://doi.org/10.1039/c3ra43180k

[158] Li, X.J., et al. (2014) Extended Petroleum Hydrocarbon Bioremediation in Saline Soil Using Pt-Free Multianodes Microbial Fuel Cells. Rsc Advances, 4, 59803-59808. https://doi.org/10.1039/C4RA10673C

[159] Zhang, Y.Y., et al. (2015) Horizontal Arrangement of Anodes of Microbial Fuel Cells Enhances Remediation of Petroleum Hydrocarbon-Contaminated Soil. Environmental Science and Pollution Research, 22, 2335-2341. https://doi.org/10.1007/s11356-014-3539-7

[160] Li, H.N., et al. (2017) A Pilot-Scale Benthic Microbial Electrochemical System (BMES) for Enhanced Organic Removal in Sediment Restoration. Scientific Reports, 7. https://doi.org/10.1038/srep39802

[161] Stoll, Z.A., et al. (2016) Interplay of Anode, Cathode, and Current in Microbial Fuel Cells: Implications for Wastewater Treatment. Energy Technology, 4, 583-592. https://doi.org/10.1002/ente.201500397 
[162] Srikanth, S., Mohan, S.V. and Sarma, P.N. (2010) Positive Anodic Poised Potential Regulates Microbial Fuel Cell Performance with the Function of Open and Closed Circuitry. Bioresource Technology, 101, 5337-5344. https://doi.org/10.1016/j.biortech.2010.02.028

[163] Goud, R.K. and Mohan, S.V. (2013) Prolonged Applied Potential to Anode Facilitate Selective Enrichment of Bio-Electrochemically Active Proteobacteria for Mediating Electron Transfer: Microbial Dynamics and Bio-Catalytic Analysis. Bioresource Technology, 137, 160-170. https://doi.org/10.1016/j.biortech.2013.03.059

[164] Zhang, F., et al. (2013) Long-Term Performance of Liter-Scale Microbial Fuel Cells Treating Primary Effluent Installed in a Municipal Wastewater Treatment Facility. Environmental Science \& Technology, 47, 4941-4948. https://doi.org/10.1021/es400631r

[165] Sasaki, K., et al. (2010) Bioelectrochemical System Stabilizes Methane Fermentation from Garbage Slurry. Bioresource Technology, 101, 3415-3422. https://doi.org/10.1016/j.biortech.2009.12.076

[166] Rozendal, R.A., et al. (2009) Efficient Hydrogen Peroxide Generation from Organic Matter in a Bioelectrochemical System. Electrochemistry Communications, 11, 1752-1755. https://doi.org/10.1016/j.elecom.2009.07.008

[167] Shantaram, A., et al. (2005) Wireless Sensors Powered by Microbial Fuel Cells. Environmental Science \& Technology, 39, 5037-5042. https://doi.org/10.1021/es0480668

[168] Donovan, C., et al. (2011) Power Management System for a 2.5W Remote Sensor Powered by a Sediment Microbial Fuel Cell. Journal of Power Sources, 196, 11711177. https://doi.org/10.1016/j.jpowsour.2010.08.099

[169] Schievano, A., et al. (2017) Floating Microbial Fuel Cells as Energy Harvesters for Signal Transmission from Natural Water Bodies. Journal of Power Sources, 340, 80-88. https://doi.org/10.1016/j.jpowsour.2016.11.037

[170] Lobo, F.L., Wang, X. and Ren, Z. (2017) Energy Harvesting Influences Electrochemical Performance of Microbial Fuel Cells. Journal of Power Sources, 356, 356-364. https://doi.org/10.1016/j.jpowsour.2017.03.067

[171] Friedman, E.S., et al. (2012) A Cost-Effective and Field-Ready Potentiostat That Poises Subsurface Electrodes to Monitor Bacterial Respiration. Biosensors \& Bioelectronics, 32, 309-313. https://doi.org/10.1016/j.bios.2011.12.013

[172] Venkidusamy, K., et al. (2016) Enhanced Removal of Petroleum Hydrocarbons Using a Bioelectrochemical Remediation System with Pre-Cultured Anodes. Science of the Total Environment, 539, 61-69. https://doi.org/10.1016/j.scitotenv.2015.08.098

[173] An, J., et al. (2010) Determination of Effects of Turbulence Flow in a Cathode Environment on Electricity Generation Using a Tidal Mud-Based Cylindrical-Type Sediment Microbial Fuel Cell. Journal of Environmental Management, 91, 2478-2482. https://doi.org/10.1016/j.jenvman.2010.06.022

[174] Arends, J.B.A., et al. (2014) Greenhouse Gas Emissions from Rice Microcosms Amended with a Plant Microbial Fuel Cell. Applied Microbiology and Biotechnology, 98, 3205-3217. https://doi.org/10.1007/s00253-013-5328-5

[175] Cao, X., et al. (2015) Simultaneous Degradation of Toxic Refractory Organic Pesticide and Bioelectricity Generation Using a Soil Microbial Fuel Cell. Bioresource Technology, 189, 87-93. https://doi.org/10.1016/j.biortech.2015.03.148

[176] Zhang, T., et al. (2010) Stimulating the Anaerobic Degradation of Aromatic Hydrocarbons in Contaminated Sediments by Providing an Electrode as the Electron Acceptor. Environmental Microbiology, 12, 1011-1020. https://doi.org/10.1111/j.1462-2920.2009.02145.x 
[177] Fang, Z., et al. (2015) Electricity Production from Azo Dye Wastewater Using a Microbial Fuel Cell Coupled Constructed Wetland Operating under Different Operating Conditions. Biosensors \& Bioelectronics, 68, 135-141.

https://doi.org/10.1016/j.bios.2014.12.047

[178] Daghio, M., et al. (2016) Anodes Stimulate Anaerobic Toluene Degradation via Sulfur Cycling in Marine Sediments. Applied and Environmental Microbiology, 82, 297-307. https://doi.org/10.1128/AEM.02250-15

[179] Gregory, K.B., Bond, D. and Lovley, D.R. (2004) Electrodes as Electron Donors for Respiration and Bioremediation. Abstracts of Papers of the American Chemical Society, 228, U638-U639.

[180] Strycharz, S.M., et al. (2008) Graphite Electrode as a Sole Electron Donor for Reductive Dechlorination of Tetrachlorethene by Geobacter lovleyi. Applied and Environmental Microbiology, 74, 5943-5947. https://doi.org/10.1128/AEM.00961-08

[181] Aulenta, F., et al. (2011) Dechlorination of Trichloroethene in a Continuous-Flow Bioelectrochemical Reactor: Effect of Cathode Potential on Rate, Selectivity, and Electron Transfer Mechanisms. Environmental Science \& Technology, 45, 8444-8451. https://doi.org/10.1021/es202262y

[182] Yu, H., et al. (2016) Enhanced Anaerobic Dechlorination of Polychlorinated Biphenyl in Sediments by Bioanode Stimulation. Environmental Pollution, 211, 81-89. https://doi.org/10.1016/j.envpol.2015.12.039

[183] Li, H.N., et al. (2017) Pilot-Scale Benthic Microbial Electrochemical System (BMES) for the Bioremediation of Polluted River Sediment. Journal of Power Sources, 356, 430-437. https://doi.org/10.1016/j.jpowsour.2017.03.066

[184] Yadav, A.K., et al. (2012) Performance Assessment of Innovative Constructed Wetland-Microbial Fuel Cell for Electricity Production and Dye Removal. Ecological Engineering, 47, 126-131. https://doi.org/10.1016/j.ecoleng.2012.06.029

[185] Liu, S.T., Feng, X.J. and Li, X.N. (2017) Bioelectrochemical Approach for Control of Methane Emission from Wetlands. Bioresource Technology, 241, 812-820. https://doi.org/10.1016/j.biortech.2017.06.031

[186] Timmers, R.A., et al. (2012) Microbial Community Structure Elucidates Performance of Glyceria Maxima Plant Microbial Fuel Cell. Applied Microbiology and Biotechnology, 94, 537-548. https://doi.org/10.1007/s00253-012-3894-6

[187] Maucieri, C., et al. (2017) A Review on the Main Affecting Factors of Greenhouse Gases Emission in Constructed Wetlands. Agricultural and Forest Meteorology, 236, 175-193. https://doi.org/10.1016/j.agrformet.2017.01.006

[188] Jahangir, M.M.R., et al. (2016) Carbon and Nitrogen Dynamics and Greenhouse Gas Emissions in Constructed Wetlands Treating Wastewater: A Review. Hydrology and Earth System Sciences, 20, 109-123. https://doi.org/10.5194/hess-20-109-2016

[189] Mander, U., et al. (2014) Greenhouse Gas Emission in Constructed Wetlands for Wastewater Treatment: A Review. Ecological Engineering, 66, 19-35. https://doi.org/10.1016/j.ecoleng.2013.12.006

[190] Kaku, N., et al. (2008) Plant/Microbe Cooperation for Electricity Generation in a Rice Paddy Field. Applied Microbiology and Biotechnology, 79, 43-49. https://doi.org/10.1007/s00253-008-1410-9

[191] Kouzuma, A., Kaku, N. and Watanabe, K. (2014) Microbial Electricity Generation in Rice Paddy Fields: Recent Advances and Perspectives in Rhizosphere Microbial Fuel Cells. Applied Microbiology and Biotechnology, 98, 9521-9526. https://doi.org/10.1007/s00253-014-6138-0 
[192] Nielsen, M.E., Reimers, C.E. and Stecher, H.A. (2007) Enhanced Power from Chambered Benthic Microbial Fuel Cells. Environmental Science \& Technology, 41, 7895-7900. https://doi.org/10.1021/es071740b

[193] Friedman, E.S., et al. (2016) Methane Emission in a Specific Riparian-Zone Sediment Decreased with Bioelectrochemical Manipulation and Corresponded to the Microbial Community Dynamics. Frontiers in Microbiology, 6, No. 1523, 1-12. https://doi.org/10.3389/fmicb.2015.01523

[194] Ren, Z.Y., et al. (2011) Characterization of Microbial Fuel Cells at Microbially and Electrochemically Meaningful Time Scales. Environmental Science \& Technology, 45, 2435-2441. https://doi.org/10.1021/es103115a

[195] Sanchez, O. (2017) Constructed Wetlands Revisited: Microbial Diversity in the -Omics Era. Microbial Ecology, 73, 722-733. https://doi.org/10.1007/s00248-016-0881-y

[196] Morato, J., et al. (2014) Key Design Factors Affecting Microbial Community Composition and Pathogenic Organism Removal in Horizontal Subsurface Flow Constructed Wetlands. Science of the Total Environment, 481, 81-89. https://doi.org/10.1016/j.scitotenv.2014.01.068

[197] Lyon, D.Y., et al. (2010) Is Resistance Futile? Changing External Resistance Does Not Improve Microbial Fuel Cell Performance. Bioelectrochemistry, 78, 2-7. https://doi.org/10.1016/j.bioelechem.2009.09.001

[198] Gajda, I., et al. (2016) Electricity and Disinfectant Production from Wastewater: Microbial Fuel Cell as a Self-Powered Electrolyser. Scientific Reports, 6, 25571.

[199] Ieropoulos, I., Pasternak, G. and Greenman, J. (2017) Urine Disinfection and in Situ Pathogen Killing Using a Microbial Fuel Cell Cascade System. PLoS One, 12, e0176475. https://doi.org/10.1371/journal.pone.0176475 